\title{
Past, ongoing, and future debate on the interplay between internationalization and digitalization
}

\author{
Mara Bergamaschi ${ }^{1} \cdot$ Cristina Bettinelli ${ }^{1}$ Elena Lissana ${ }^{1}$. \\ Pasquale Massimo Picone ${ }^{2}$
}

Accepted: 29 October 2020 / Published online: 19 November 2020

(c) The Author(s) 2020, corrected publication 2021

\begin{abstract}
The interplay between internationalization and digitalization (IDI) is a relatively young research domain that is finding its way into numerous academic journals, which motivates us to systematically portray the proceedings and evolutions of this interplay over time, analyze its methodological and theoretical background and, more importantly, provide insights to guide future research on these phenomena. Combining qualitative and quantitative approaches, we analyze 68 peer-reviewed international business and management papers to explore the structure of knowledge production and identify the emerging trends. Our research reveals four key stages of the debate: (a) how IDI influences interorganizational aspects (1996-2004), (b) how digitalization influences the balance between perceived risk and returns in internationalization (2005-2009), (c) how digital advances and available internationalization channel alternatives influence IDI (2010-2014), and (d) how IDI influences intraorganizational aspects (2015-2019). Moreover, our analysis reveals heterogeneity across theoretical perspectives, methods, and research themes over the years. Finally, we identify theoretical and methodological challenges related to IDI research.
\end{abstract}

Keywords Internationalization strategy · Digital innovation · Digitization · International business · Information technology $\cdot$ Literature review

\section{Introduction}

In recent decades, management studies have acknowledged digital transformation (or digitization; i.e., the "technical process of converting analog signals into digital form"; Legner et al. 2017, p. 301) as one of the most relevant phenomena shaping the evolution of the business world and, by and large, societies

Mara Bergamaschi

mara.bergamaschi@unibg.it

Extended author information available on the last page of the article 
(Parviainen et al. 2017; Tihinen et al. 2016). Correspondingly, scholars have paid attention to the "sociotechnical phenomena and processes of adopting and using [digital] technologies" (Legner et al. 2017, p. 301), namely, firms' digitalization. The common ground of such studies is that digitalization is changing how firms orchestrate their resources and interact with one another (Luz Martín-Peña et al. 2018; Parviainen et al. 2017).

At the same time, the international business literature has revealed that firms' are increasingly making decisions to sell their products in many countries and meet multiple market demands or move, partially or entirely, production abroad (Grant 2016). Correspondingly, scholars have attempted to disentangle the antecedents (with a special focus on transactions, resources, locations, and institutions; Cuervo-Cazurra et al. 2018, 2019; Matysiak and Bausch 2012) and consequences (Kirca et al. 2012) of this internationalization.

Recently, the international business research has recognized that digitalization represents a primary antecedent and critical factor of internationalization (Joensuu-Salo et al. 2018; Kotha et al. 2001; Singh and Kundu 2002). During the last three decades (and especially the most recent one), great innovations in digitalization have reshaped the task environment and redesigned international strategies: innovative technologies have facilitated firms in reducing their transaction costs (Yamin and Sinkovics 2006), favoring communication, carrying out information interchanges and integration among partners, suppliers, customers and distributors (Alarcón-del-Amo et al. 2018; Kim et al. 2018; Özcan et al. 2018; Vasilchenko and Morrish 2011), reducing distances (Liu et al. 2016; Sinkovics et al. 2011), supporting the emergence of synergies in production (Jean et al. 2010), reshaping firm boundaries (Chen and Kamal 2016), and reconfiguring operations and the supply chain by reducing location dependencies (Jean et al. 2010; Strange and Zucchella 2017). Moreover, digitalization has permitted the identification of new market opportunities (Chen and Kamal 2016; Watson et al. 2018) and allowed for easy access to resources, capabilities and knowledge in foreign countries (Charalabidis et al. 2015; Coviello et al. 2017).

As argued by Sinkovics et al. (2013), the possibility of exploiting the benefits of digitalization on a large scale has pushed international firms to invest in it. Moreover, "to add to the increased demand from customers, companies are facing ever tougher competition due to globalization and pressurization to go digital before others do, seeking to survive and attain competitive advantages" (Reis et al. 2018, p. 411).

The implications of the interplay between digitalization and internationalization (IDI) seem to have become compound, complex, interconnected and bidirectional. As the relationship between internationalization and digitalization is becoming increasingly varied, intertwined and complex, digitalization needs be addressed at the scientific level in the fields of international research (Kraus et al. 2018).

The combined study of internationalization and digitalization provides increased knowledge as to their interplay, underlining the need for managers to reassess their choices and for scholars to identify future research patterns. As we are still in the early stages of the digital era and the digitalization process has been changing 
exponentially in recent years, the examination of the opportunities and risks of this interplay is fundamental and essential for scholars and practitioners. The stream of research that considers firms' internationalization and digitalization as intertwined phenomena was initiated by Lovelock and Yip in 1996 (e.g., Gilson et al. 2015; Kotha et al. 2001; Leamer and Storper 2001).

Despite this, most of the research on internationalization and digitalization has been conducted over the last decade; however, studies have focused on specific pieces of digitalization (i.e., the internet, social networking, big data and analytics, mobility and pervasive computing, cloud computing, social media, and artificial intelligence) and internationalization (from upstream production to downstream markets; Rask 2014), providing a partial and fragmented picture and of the interplay between them.

A first inspection of the available literature shows a lack of wide-ranging and analytical scrutiny of this interconnection; although we found five reviews that focus on digitalization and internationalization as intertwined phenomena, none of them provides an inclusive representation of the content and evolution of the knowledge on these two macro themes, as studied together. Moreover, these reviews focus on some specific aspects of digitalization (Eduardsen and Ivang 2016; Reuber and Fischer 2011) and internationalization (Vadana et al. 2019; Watson et al. 2018) or focus on a specific type of firm (Wittkop et al. 2018) or country (Mendes 2020). All of them fall short in presenting the full picture of the literature on IDI, although more than 20 years have passed since attention began to be paid to this research domain (Lovelock and Yip 1996).

We believe that now is the time to shed light on how the interplay of digitalization and internationalization has been explored in the widespread literature on international business and general management to offer a more complete picture than previous reviews, comprehensive of insights across countries and industries. This will allow for the provision of guidance for practitioners and the identification of future research avenues for scholars. Therefore, we propose the following research questions. What is the structure of the IDI domain? How did the related research develop over time? What emerges that is of interest to practitioners and scholars studying this evolution? What are the future patterns of the research? Consequently, with the aim of answering the above questions, the purpose of this article is threefold. First, we aim to provide a clear representation of the extant literature on IDI in the management and internationalization fields and the knowledge base from which it draws. Second, we aim to investigate the historical evolution of this interplay and identify why this evolution allows managers to better integrate digitalization and internationalization. Third, we aim to unveil a fertile research agenda for scholars.

To comprehensively assess the extant literature, we combine the quantitative and qualitative interpretations of 68 peer-reviewed papers in journals belonging to the international business and general management fields. This choice of journals allows us to recognize and understand the state of the art of the relevant research in a unique frame, avoiding the specificities by which these themes can be addressed in other disciplines. Moreover, the debate around IDI seems to have first been called to attention in these fields (Wright and Ricks 1994). 
The choice to implement a quantitative and qualitative analysis of papers allows us to benefit from the complementarity between the two approaches and offers a more comprehensive understanding of this literature. Specifically, the quantitative approach allows us to gain a relatively more objective and systematic understanding of the literature (Nerur et al. 2008). The qualitative approach makes it possible to provide a thorough analysis of the main focus of the research, theories used, research design and conceptualizations chosen, methodological challenges, and the role played by focus variables (Bos and Tarnai 1999; Saggese et al. 2016). Combining these approaches facilitates a better understanding and a clearer view of the structure and inner attributes of the debate on IDI, making it possible to identify the potential challenges and recommendations for scholars on the positioning of their future research efforts.

The paper is organized as follows: Section 2 offers a brief overview of digitalization and internationalization as separate and interrelated phenomena. Section 3 explains our quantitative and qualitative research approach. Sections 4 and 5 show our results and analytically discuss them. Finally, Sect. 6 presents discussions, a research agenda and limitations.

\section{Conceptualization overview}

\subsection{Digitalization}

Digitalization is commonly seen as one of the most relevant phenomena shaping the evolution of the business world and, by and large, societies (Cortellazzo et al. 2019; Parviainen et al. 2017; Tihinen et al. 2016). Several scholars have compared the reach of digitalization to that of the industrial revolution (Degryse 2016; Schwab 2016; Tihinen et al. 2016). Arguably, as Stolterman and Fors (2004, p. 689) posit, digitalization regards "the changes associated with the application of digital technology in all aspects of human society".

A literature review provided by Legner et al. (2017) shows that with developments in digital technology, we might observe three phases of how digitalization is affirmed in the business world. The first wave emphasizes the positive aspects of information and communication technology in terms of the automation of routines (e.g., Adetayo et al. 1999; D'Mello and Sahay 2007). In this regard, Adetayo et al. (1999, p. 692) call attention to the "processes that together collect, retrieve, process, store and disseminate information for the purpose of facilitating, planning, control, coordination and decision-making in organizations".

The second wave emphasizes the benefits of the World Wide Web (Legner et al. 2017). As is known, this ultimately represents an opportunity for business model innovations that imply radically changing and rethinking value creation (and cocreation) through internal and external interactions with stakeholders, value capture and value delivery (Autio 2017; Joensuu-Salo et al. 2018; Legner et al. 2017).

Today, we are facing the third wave of digitalization (Legner et al. 2017), which encompasses the Internet of Things, big data, robotic systems, additive 
manufacturing (Strange and Zucchella 2017), and the enormous power involved in the storing and processing capacities of computers (Legner et al. 2017). For example, big data and business analytics are becoming important elements that firms will need to implement throughout their organization to obtain a deeper, improved appreciation of internal and external activities and make well-informed managerial and strategic decisions (Charalabidis et al. 2015). Similarly, it is a common understanding that the Internet of Things will also bring about several product and service innovations (Andersson and Mattsson 2015). Cloud systems, the automation of knowledge, and advances in data analytics and in machine learning are becoming less expensive than in the past and, thus, are growing exponentially in terms of capabilities and power (Chen and Chen 2015).

In summary, innovations in digital technologies are completely reshaping the business environment and providing firms with new opportunities. Distinctive types of digital technologies, such as information and communication technology (ICT), the internet, e-commerce, social networking, the Internet of Things, data and analytics, robotic systems and additive manufacturing, allow firms to obtain competitive advantages (Lee and Falahat 2019); reduce transactional costs and information asymmetries (Yamin and Sinkovics 2006); improve productivity, integration, interaction and knowledge sharing inside and outside the organization (Alberti-Alhtaybat et al. 2019; Andersson et al. 2016; Coviello et al. 2017; Zaheer and Manrakhan 2001); expand connectivity among firms, suppliers and clients, as well as the discovery and exploitation of new business opportunities, reducing physical distance and location dependencies (Jean et al. 2010; Kim et al. 2018; Özcan et al. 2018; Sinkovics et al. 2011, 2013; Strange and Zucchella 2017); accelerate knowledge creation (Foss and Pedersen 2004); facilitate vertical disintegration and specialization (Alcácer et al. 2016; Langlois 2002); allow for entry into new markets (Chen and Kamal 2016; Watson et al. 2018); and generate new business models (Frank et al. 2019), altering the physical boundaries (Chen and Kamal 2016) and tasks of firms and where the activities are located, shifting the frontiers of automation toward knowledge workers, and encouraging the emergence of a new "chapter" for firms (Charalabidis et al. 2015). In this "chapter", special attention will be devoted to sustainability (Ghobakhloo 2019; Parida et al. 2019) and the servitization of manufacturing (Luz Martín-Peña et al. 2018).

In short, there is extensive recognition among scholars of the rapidly changing role of digital technologies and their positive effects on firms and the business environment. However, contradictions have emerged in relation to the downsides of digitalization. Firms can see market opportunities in digitalization, but competition is increasing at the same time, and the competitive advantage originating from digitalization alone is usually only temporary (Bürgin and Meyer 2020). The multiple ways in which to exploit digitalization and its effects on the business world have resulted in blurred boundaries of the phenomenon and solicited a comprehensive analysis of the literature.

Drawing on some authoritative authors (Acker et al. 2012) and reviews (Legner et al. 2017; Luz Martín-Peña et al. 2018) and to identify an inclusive definition, we consider digitalization as a sociotechnical phenomenon, emerging both at the firm level and at the interfirm level (Seyedghorban et al. 2020), by implementing 
information, communication, and digital technologies (Pihir et al. 2019), which include industry 4.0, the Internet of Things, big data, e-commerce, e-cloud, blockchain, artificial intelligence, machine learning, technological platforms, social media, and social networks.

\subsection{Internationalization}

Internationalization represents a fundamental strategy for firm expansion ( $\mathrm{Lu}$ and Beamish 2001), as it offers the opportunity to reach new markets, attract new customers; achieve economies of scale and scope; enhance capabilities and flexibility; diversify risks; access new knowledge, capabilities and technologies; and avoid strong competition in home markets (Elango 2004).

Unsurprisingly, more than in the past, this ongoing process is pushing increasingly more firms to develop their market reach and/or operations abroad, shifting from national to international markets (Dess et al. 2014; Wheelen and Hunger 2012). Accordingly, the literature on internationalization usually considers internationalization as ranging from upstream production to downstream markets (Rask 2014). Indeed, two separate dimensions exist with regard to firm internationalization, with one relating to a firm's market sphere and the other relating to its production sphere. Focusing on the market sphere of internationalization, we call attention to "the process of creatively discovering and exploiting opportunities that lie outside of a firm's domestic markets in the pursuit of competitive advantage" (Zahra and George 2002 , p. 260). Regarding the production sphere of internationalization, we observe that internationalization is related to global sourcing and allocation processes (Rask 2014). Accordingly, managing operations in different countries has become a critical issue for managers (Casillas and Acedo 2013; Hitt et al. 2006). Despite the bulk of the literature being focused on the internationalization process, some firms have been established directly on a global scale (Chabowski and Mena 2017).

Given the growing importance of internationalization, scholars are making extensive efforts to unveil the antecedents of internationalization. From a strategic perspective, we distinguish (a) the specific variables of the task environment (i.e., external variables) and (b) organizational structures, processes and resources (i.e., internal variables), which appear to be the key drivers of a firm's decision to internationalize (Hitt et al. 2006). The main external variables are the stability and effectiveness of the political and legal environment (Tan and Chintakananda 2016), governance quality (Fainshmidt et al. 2016), and the similarity of industry architectures of home and host countries (Jacobides and Kudina 2013). Internal variables relating to international growth are focus on product differentiation (Bloodgood et al. 1996), proprietary capabilities (in technology and marketing, for instance) (Asmussen and Goerzen 2013), learning from early entries (Chang 1995), and financial resources (Dagnino et al. 2019). From a governance perspective, authors show that conflicts between managers and shareholders and those among shareholders are crucial antecedents of the choice to enter new country markets (D'Angelo et al. 2016; Majocchi and Strange 2012). 
Furthermore, the relationship between internationalization and performance seems to be affected by internal strategic factors (such as innovation, learning, and organizational structures; Hitt et al. 2006) and external variables (such as home country institutions; Marano et al. 2016). More specifically, we call attention to the "liability of foreignness" (Zhou and Guillen 2016) and the multidimensional distance between firm and target countries (Hutzschenreuter et al. 2016), with a special focus on cultural distance (Beugelsdijk et al. 2017, 2018).

As can be seen, in the recent literature on internationalization, scholars have paid particular attention to both positive and negative performance effects (Cardinal et al. 2011; Lampel and Giachetti 2013; Lu and Beamish 2004); indeed, although firms' internationalization activates and allows them to seize different opportunities, it also increases coordination costs.

Therefore, since scholars have recognized the growing importance of internationalization, the vastness of its borders, the complexity of its antecedents and of its effects on firm performance, and its contradictions, a substantial ambiguity emerges in its conceptual definitions, making it difficult to have a shared delineation that allows for an inclusive synthesis. Therefore, to achieve a comprehensive analysis of the literature, we employ the following broad definition of internationalization: a firm's decision to produce (international operations) and/or sell its products in a different country.

\subsection{Digitalization and internationalization}

As reported in the introduction, the study of Lovelock and Yip (1996) was the first to analyze the interplay between digitalization and internationalization. Specifically, the authors recognized information technology as an industry globalization driver (combined with favorable logistics, government policies, and so on).

However, when summarizing the evolution of international management research six years later, Werner (2002) did not explicitly acknowledge digitalization as a key variable in internationalization. Similarly, in 2011, Liesch et al. did not emphasize digitalization at all. Remarkably, as Charalabidis et al. (2015) reported in their editorial, digitalization shapes organizational structures and processes and consequently allows firms to access larger production factor markets and penetrate new country markets. In the past decade, scholars have noted that digitalization is becoming a condition for international competitiveness (Ghobakhloo 2019; Kutnjak et al. 2019).

The effects of digitalization reported above (i.e., reduction in transaction costs, improvement of coordination, reduction in distance, and reconfiguration of the supply chain) confirm that digitalization is an important antecedent of internationalization (Biggiero 2006; Zucchella et al. 2007). From a complementary perspective, we can infer that internationalization amplifies the benefits of digitalization; however, studies that analyze the effect of internationalization on digitalization, such as those that highlight the potential risks, are far fewer in number.

To have a complete overview that allows for increased knowledge of IDI and to fully acknowledge its potential benefits and risks, the combined study of internationalization and digitalization appears to be essential. 
Remarkably, analyzing the five literature reviews that focus on IDI, we acknowledge that all of them take insights from a specific stream of the literature and offer only a partial picture of the content and evolution of the knowledge of these two macro themes. More specifically, Watson et al. (2018) explore the literature focused on how digital technologies shape international relationship-marketing strategies to provide a "description of the evolution of international market entry research" (p. 30). Vadana et al. (2019) focus on the relationship between digitalization and international entrepreneurship and marketing to "provide a consistent picture of how value-chain digitalization affects companies' internationalization and international marketing" (p. 471) in born-global firms in high-tech industries, though digitalization is pervasive in other long-established industries as well. Furthermore, given their focus on born-global companies, Vadana et al. (2019) mainly investigate large companies. Reuber and Fischer (2011) examine the academic debate on firms gaining an international competitive advantage in internet-enabled markets. They recognize the importance of online reputation, online technological capabilities and online brand communities, as considered from the firm perspective. Eduardsen and Ivang (2016) investigate internetenabled internationalization, considering only one side of the interplay between internationalization and digitalization, i.e., "the increasing involvement of firms in international markets through the utilization of the Internet" (p. 152). Finally, Mendes (2020) analyzes the relationship between internationalization and digitalization with both a specific and country focus.

Considering that all the reviews analyzed are partial, we see an opportunity to comprehensively analyze the literature on IDI in the international business and general management streams. Specifically, the consideration of both sides of the relationship (i.e., the impact of digitalization on internationalization and vice versa) and the two streams of the literature allows us to offer a more complete picture, to highlight insights across countries and industries and to recognize the innovative paths of study.

\section{Method}

To examine the structure of knowledge production, trace its evolution, and identify the key methodological patterns in the IDI literature, we selected papers to include in the sample, and then, we combined quantitative and qualitative analyses of extant studies.

Figure 1 summarizes the stages of the process. 
JOURNAL SELECTION

Journals from the "international business" and "general management" categories ranked 2 or above by Association of Business Schools (ABS)

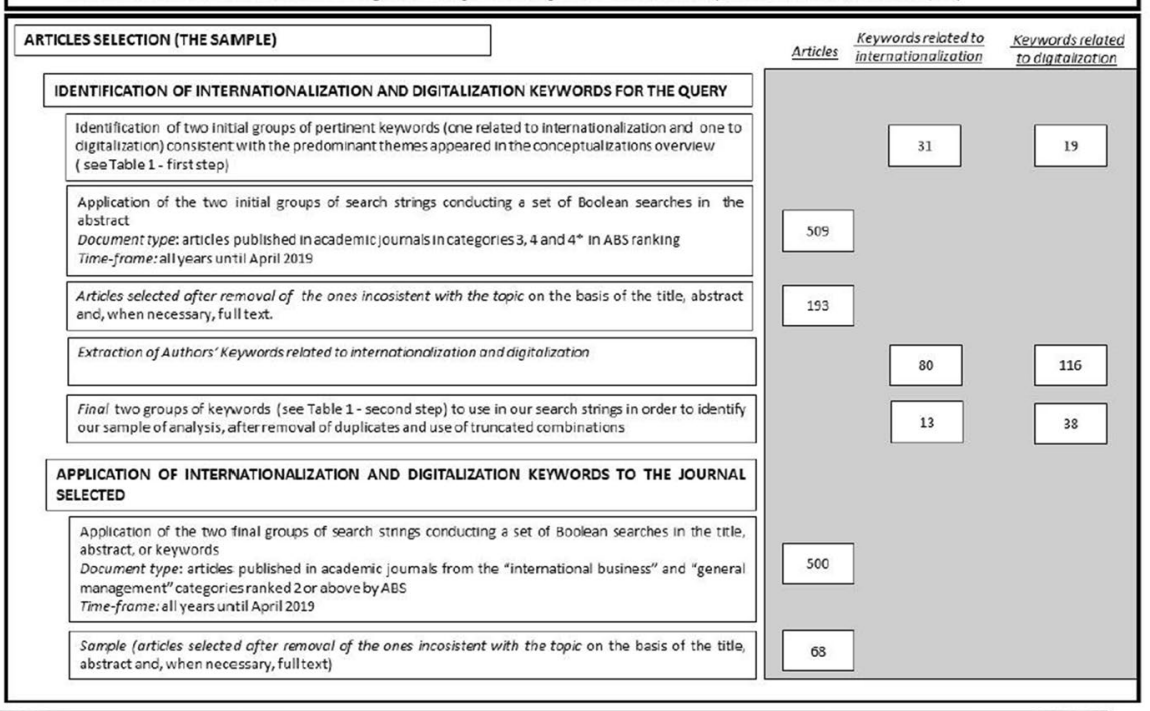
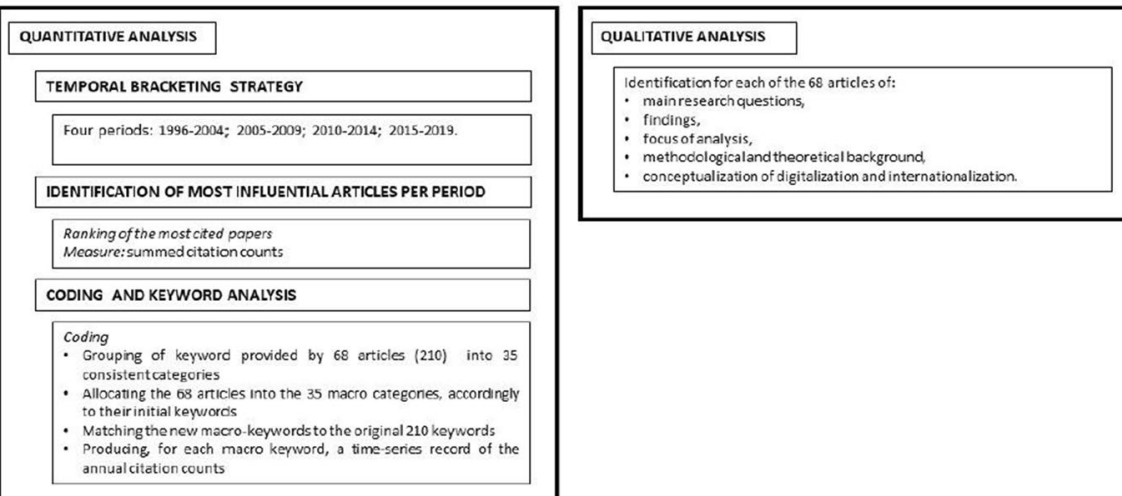

Fig. 1 The stages of the process

\subsection{Sample definition}

\subsubsection{Journal selection}

Considering our focus on international business and management studies, we selected journals from the international business and general management categories ranked 2 or above by the Association of Business Schools (ABS Academic Journal Guide 2018) (e.g., Franco-Santos and Otley 2018). The choice of these categories allows us to focus on the principal representations in the international business and management literature. We believe that this strategy is a good starting point for offering an overview of the IDI literature for at least two reasons. 
First, the consideration of international business and general management journals allows us to outline the state of the art of the relevant research in a unique frame, shape ongoing work, and set new horizons for inquiry. This choice does not offer a complete understanding of all approaches to IDI (which is not our intention). We clearly recognize that internationalization and digitalization may also be discussed in other disciplines, such as finance and operations. In any case, including journals from other disciplines would not allow us to build a clear analysis framework due to the specificities with which the themes of internationalization and digitalization can be addressed in different research areas. Second, the debate on IDI seems to have first been considered in the fields of international business and general management. Indeed, Wright and Ricks (1994) were among the first researchers to call for studies on IDI in their research agenda referring to internationalization.

Given its design centered around the literature on international business and general management, our analysis will ignore specific themes related to other disciplines but will provide a clearer definition of the development of that which can be considered the core of a domain. The list of journals selected is provided in Appendix 1.

\subsubsection{Article selection (the sample)}

To apply a string-search-based method to the journals selected to identify the articles for our review, we combined different methodologies and conceived a multistep process aimed at creating two lists of keywords that include the different facets of internationalization and digitalization and lessen the blurring of the boundaries between these two themes. This approach was inspired by Martin (2012) and Jurowetzki et al. (2018).

Consistent with the predominant themes that appeared in the conceptualization overview, we first developed two sets of pertinent keywords, the first related to internationalization and the other related to digitalization (Chabowski et al. 2011; Cornelius et al. 2006; Furrer et al. 2008; Schildt et al. 2006) (see Table 1, first step). These lists of keywords were our starting point. The first string-based strategy was applied to search for EBSCO publications. According to the authority-based approach and following Atewologun et al. (2017), we selected "seed" journals (categories 4*, 4 and 3 of ABS Academic Journal Guide 2018). We imposed a query according to which each publication should include at least one keyword related to internationalization and one related to digitalization in its abstract, and were left with a total of 509 papers. To avoid false positives and be sure of the proper identification of the list of publications inherent to IDI, we filtered the papers by examining the title, keywords, abstract and, when necessary, the full text of each article. This process was carried out independently by two of the authors. In the few cases in which the authors did not agree about the inclusion of the paper in the database, the judgment of a third author was considered. The result was a list of 193 appropriate papers.

In the second step, we extracted all authors' keywords related to internationalization and digitalization from the 193 papers. Then, we removed duplicates (plurals and words with different orders) and used truncated combinations to find the final two groups of keywords to use in our search strings to identify our analysis sample (see Table 1, second step). The benefit of our multistep approach to finding the pertinent keywords to use in the string-search-based method to 
Table 1 List of keywords

\begin{tabular}{|c|c|c|}
\hline & Internationalization keywords & Digitalization keywords \\
\hline First step & 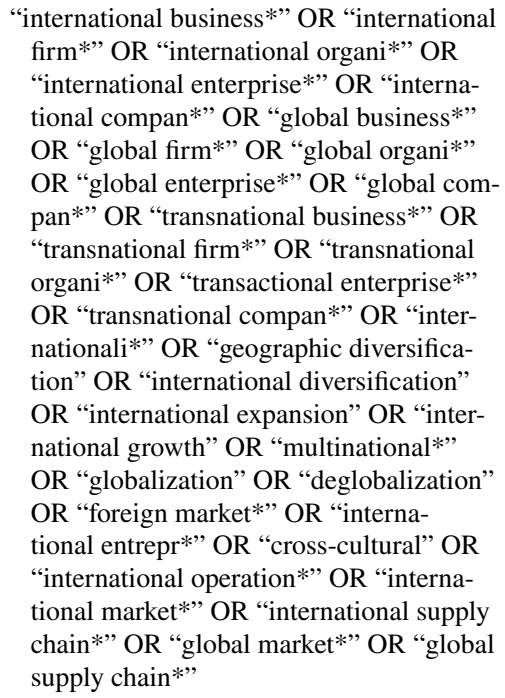 & 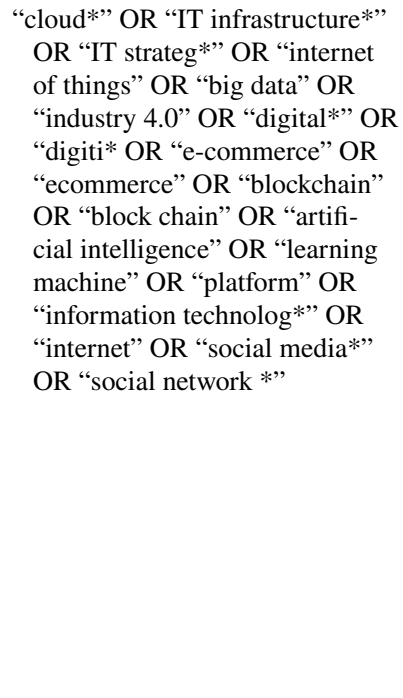 \\
\hline Second step & $\begin{array}{l}\text { "geographic diversification" OR “cross- } \\
\text { border" OR "export*” OR "foreign" } \\
\text { OR "global*” OR "international*" OR } \\
\text { "country of origin" OR "multinational*" } \\
\text { OR "offshor*” OR "psychic distance" } \\
\text { OR "country risk" OR "entry mode" OR } \\
\text { "Uppsala model” }\end{array}$ & 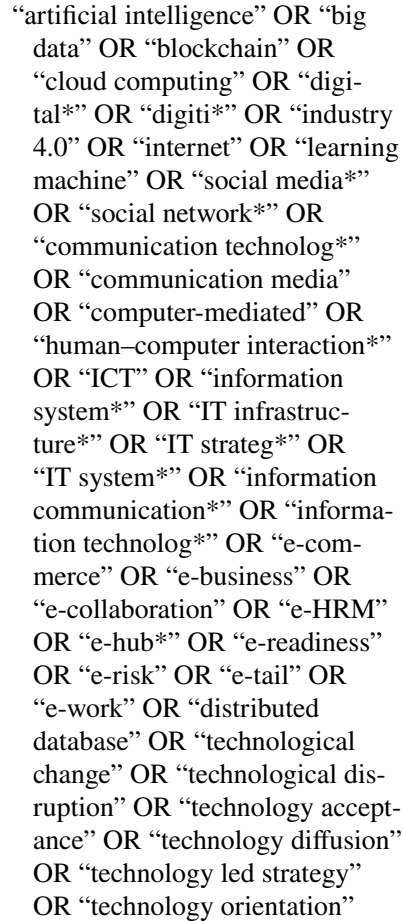 \\
\hline
\end{tabular}


identify the analysis sample is that it allows for a broad consideration of that which can be considered consistent with an inclusive definition of internationalization and digitalization.

Finally, we applied the two final groups of search strings to conduct a set of Boolean searches in the title, abstract, or keywords of the journals selected, as reported in the previous paragraph (Furrer et al. 2008; Saggese et al. 2016; Sarto et al. 2014; Torchia et al. 2015).

The last search strategy led to 500 papers. For each of the 500 papers, two of the authors independently reviewed the title, keywords, abstract and, when necessary, the full text of each paper to be sure to only select articles concerning the interplay between internationalization and digitalization. Additionally, in this case, in the few cases in which the authors did not agree about the inclusion of the paper in the database, the judgment of a third author was considered. The final sample consisted of 68 articles published in 19 journals (see Appendix 2).

\subsection{Quantitative analysis}

The quantitative analysis task was threefold: first, to perform a descriptive analysis of our sample to ascertain the historical development of the literature and its development within journals and authors; second, to pinpoint the most relevant papers for each phase; and third, to gain insight into the structure of the domain by studying how the keywords changed over time. We framed our research in many steps to obtain these results: (a) temporal bracketing strategy selection; (b) the identification of the most influential articles; and (c) coding and keyword analysis. We developed our analysis by using the Software bibliometrix (Aria and Cuccurullo 2017).

\subsubsection{Temporal bracketing strategy}

Since the key features of a broad interplay such as that between internationalization and digitalization can present significant evolutions over time, consistent and meaningful results are more likely to emerge by looking at specific periods. Considering specific periods of time may also show the longitudinal development of these interplay dynamics and maximize both continuity and discontinuity within each phase of the literature and among them (Langley and Truax 1994).

Consequently, following Chabowski et al. (2011), we divided our papers into four five-year periods starting in 2004. The pre-2004 periods proved difficult because the data in the previous years were insufficient for identifying specificities and common paths. Therefore, consistent with Rakas and Hain (2019), to improve this situation, we combined the data and formed a single period between 1996 and 2004 (the period of origin).

The papers were distributed as follows: nine articles in the period 1996-2004, six articles in the period 2005-2009, 13 articles in the period 2010-2014, and 40 articles in the period 2015-2019. 


\subsubsection{Identification of the most influential articles per period}

Because there are always certain publications that play a key role in development in every field (Berry and Parasuraman 1993), it is crucial to recognize the most influential IDI papers per period. To define and measure the extent to which a paper can be considered "influential", we adopted the commonly used method of summed citation counts (Bergh et al. 2006; Furrer et al. 2008; Ramos-Rodríguez and Ruíz-Navarro 2004).

\subsubsection{Coding and keyword analysis}

To gain insight into emerging concepts, we coded and analyzed the content of all papers.

We created a list of 35 macro keywords starting from the full list of keywords provided in the 68 articles (sample) and regrouping them into consistent categories (Cuccurullo et al. 2016; Furrer et al. 2008; Rugg and McGeorge 1997) ${ }^{1}$ (see Table 2). This step was necessary because of the high number of distinctive keywords in our sample (210), many of which were used only once, thereby reducing the reliability of the analysis.

This process was performed independently by two of the authors. In the few cases in which they did not agree on the grouping, the judgment of a third author was considered.

We then allocated the 68 articles into the 35 macro categories according to their initial keywords. After doing this, we produced a time-series record of the annual citation counts for each macro keyword. This step was helpful for understanding how the use of various macro categories rose and declined over time and their academic popularity.

\subsection{Qualitative analysis of papers}

To obtain an overview of the methodological (main focus of the research, theories used, research design and conceptualizations chosen, methodological challenges, and the role played by the focus variables) and theoretical background and to look inside its evolution and that related to the content in different periods, we systematically analyzed the 68 selected papers. At least two authors read and coded each paper, identifying the main research questions, findings, analysis focus, methodological and theoretical background, and conceptualization of digitalization and internationalization. This was done by the authors individually and then discussed iteratively with the other authors to manage discrepancies or doubts regarding the coding.

\footnotetext{
1 When a paper did not include keywords (for instance, Globerman et al. 2001; Lagerström and Andersson 2003; Rangan and Sengul 2009), the authors independently read the papers and identified five keywords. We selected the keywords that emerged more frequently among those selected by each author.
} 
Table 2 List of macro-keywords

\begin{tabular}{|c|c|}
\hline Macro-keywords & Keywords \\
\hline Alliance/Ties & $\begin{array}{l}\text { Alliance, Boundary spanning, Bridging tie, Business } \\
\text { relationship, Business tie, Global linkage, International } \\
\text { exchange relationship, International link }\end{array}$ \\
\hline Born global & Born global \\
\hline Capability & $\begin{array}{l}\text { Dynamic capability, Internet marketing capability, } \\
\text { Misalignment capability, Internet capability, Network } \\
\text { capability }\end{array}$ \\
\hline Context & $\begin{array}{l}\text { Agricultural sector, Aramex, Business consulting organiza- } \\
\text { tion, Chile, Consumer goods versus industrial goods } \\
\text { industry, Country of origin, Developing country, Emerg- } \\
\text { ing market, Emerging market multinational, Global } \\
\text { industry, Indian SME, Industrial organization, Industrial } \\
\text { sector, Korean SME, Lindblom, Off-highway plant and } \\
\text { machinery, Olive oil sector, Peru, Retail brokerage indus- } \\
\text { try, Russia, Service, Service business, Sharing economy, } \\
\text { Uber, UK }\end{array}$ \\
\hline Control & Control, Monitoring \\
\hline Digital platform & $\begin{array}{l}\text { Digital platform, Digital work, Platform, Platform interna- } \\
\text { tionalization, Third-party portal }\end{array}$ \\
\hline Disruptive technology & $\begin{array}{l}\text { Disruptive, Disruptive technology, Technological disrup- } \\
\text { tion }\end{array}$ \\
\hline E-commerce & $\begin{array}{l}\text { E-commerce, Electronic business, Internet marketing, } \\
\text { Online retailer }\end{array}$ \\
\hline Entrepreneurship & $\begin{array}{l}\text { Entrepreneurial, Entrepreneurship, International entrepre- } \\
\text { neurship, International entrepreneurship characteristic }\end{array}$ \\
\hline Entry mode & Foreign direct investment \\
\hline Environmental uncertainty & Environmental turbulence, Environmental uncertainty \\
\hline Export & Export, Export market growth, Exporting, Exporting firm \\
\hline Group/Team & $\begin{array}{l}\text { Group process, Team, Virtual integration, Virtual team, } \\
\text { Virtuality }\end{array}$ \\
\hline Hq-subsidiary relationship & $\begin{array}{l}\text { Corporate hq, Hq-manager, Hq-subsidiary relation, Sub- } \\
\text { sidiary autonomy, Subsidiary manager, Subsidiary role }\end{array}$ \\
\hline Information and communication technology & $\begin{array}{l}\text { Computer system, Computer-based system, Computeriza- } \\
\text { tion, Information and communication technology, Infor- } \\
\text { mation availability, Information processing, Information } \\
\text { technology, Information technology investment, It/is } \\
\text { infrastructure, networking technology }\end{array}$ \\
\hline Innovation & Innovation, Innovativeness, Novelty level \\
\hline Integration/coordination & $\begin{array}{l}\text { Cooperativeness, Coordination, Integration, Personal and } \\
\text { electronic-based coordination mechanism }\end{array}$ \\
\hline Internationalization process & International business process, Internationalization speed \\
\hline Internet & $\begin{array}{l}\text { Electronic access, Internet, Internet infrastructure, Online, } \\
\text { Technology enabled consumer, Web }\end{array}$ \\
\hline Knowledge & $\begin{array}{l}\text { Experiential knowledge, Intangible, Intellectual capital, } \\
\text { Knowledge, Knowledge management, Knowledge shar- } \\
\text { ing and management, Reverse knowledge transfer }\end{array}$ \\
\hline Market & Heterogeneous market, Multi-sided market \\
\hline
\end{tabular}


Table 2 (continued)

\begin{tabular}{|c|c|}
\hline Macro-keywords & Keywords \\
\hline Market entry/selection & $\begin{array}{l}\text { Foreign market entry, International market entry, Interna- } \\
\text { tional market growth, Market selection }\end{array}$ \\
\hline Marketing & $\begin{array}{l}\text { Communication culture, Cross cultural marketing, Custom- } \\
\text { ization, Pricing decision, Product innovation, Purchasing } \\
\text { intention, Word of mouth }\end{array}$ \\
\hline MNE & $\begin{array}{l}\text { Global factory, Multinational corporation, Multinational } \\
\text { enterprise (MNE) }\end{array}$ \\
\hline Network & $\begin{array}{l}\text { Business network, Cluster, Innovation network, Network, } \\
\text { Network effect, Network relationship }\end{array}$ \\
\hline New digital technology or Industry 4.0 & $\begin{array}{l}\text { Additive manufacturing, Big data, Big data and analytics, } \\
\text { DEA, Distributed digital manufacturing, Industry 4.0, } \\
\text { Internet of things, Robotic }\end{array}$ \\
\hline Organizational features & $\begin{array}{l}\text { Agile, Asset-light, Intra-organizational structure, Organiza- } \\
\text { tion structure, Organizational agility, Outsidership }\end{array}$ \\
\hline Performance & $\begin{array}{l}\text { Economy of scale, Efficiency, Financial performance, Firm } \\
\text { performance, Performance, Performance of cross-border } \\
\text { M\&A, Strategic performance }\end{array}$ \\
\hline Psychic distance & $\begin{array}{l}\text { Cultural distance, Distance, Diversity, Embeddedness, } \\
\text { National culture, Psychic distance }\end{array}$ \\
\hline Risk & Country risk, E-risk, Misappropriation, Risk \\
\hline SME & Small firm, SME \\
\hline Social media/social network & $\begin{array}{l}\text { Brand social media, Facebook, Online social network, } \\
\text { Social media, Social media strategy, Social network, } \\
\text { Social network site }\end{array}$ \\
\hline Strategy/competitive advantage & $\begin{array}{l}\text { Active online internationalization, Business model, Busi- } \\
\text { ness strategy, Channel strategy, Competitive advantage, } \\
\text { Competitive and cooperative activity, Competitive } \\
\text { strategy, Early-mover advantage, Firm competitiveness, } \\
\text { Global marketing strategy, Global strategy, Governance, } \\
\text { Imitability, International competitiveness, International } \\
\text { diversification, Locate activities internationally, Loca- } \\
\text { tion of economic activity, Market leader versus market } \\
\text { follower, MCN expansion, Regional strategy, Strategic } \\
\text { activity, Strategic contradiction, Strategic entry, Strategic } \\
\text { orientation }\end{array}$ \\
\hline Supply chain & $\begin{array}{l}\text { Buyer-supplier relationship, Customer enquiry manage- } \\
\text { ment (CEM), Fragmentation, Global supply chain, } \\
\text { Global supply chain management, Global supply chain } \\
\text { relationship, Global value chain, Intra-firm trade, } \\
\text { Operational integration, Outsourcing, Sourcing, Supplier } \\
\text { responsiveness, Supply chain, Trust }\end{array}$ \\
\hline Technological issues & $\begin{array}{l}\text { Technological change, Technological innovation capability, } \\
\text { Technology }\end{array}$ \\
\hline
\end{tabular}




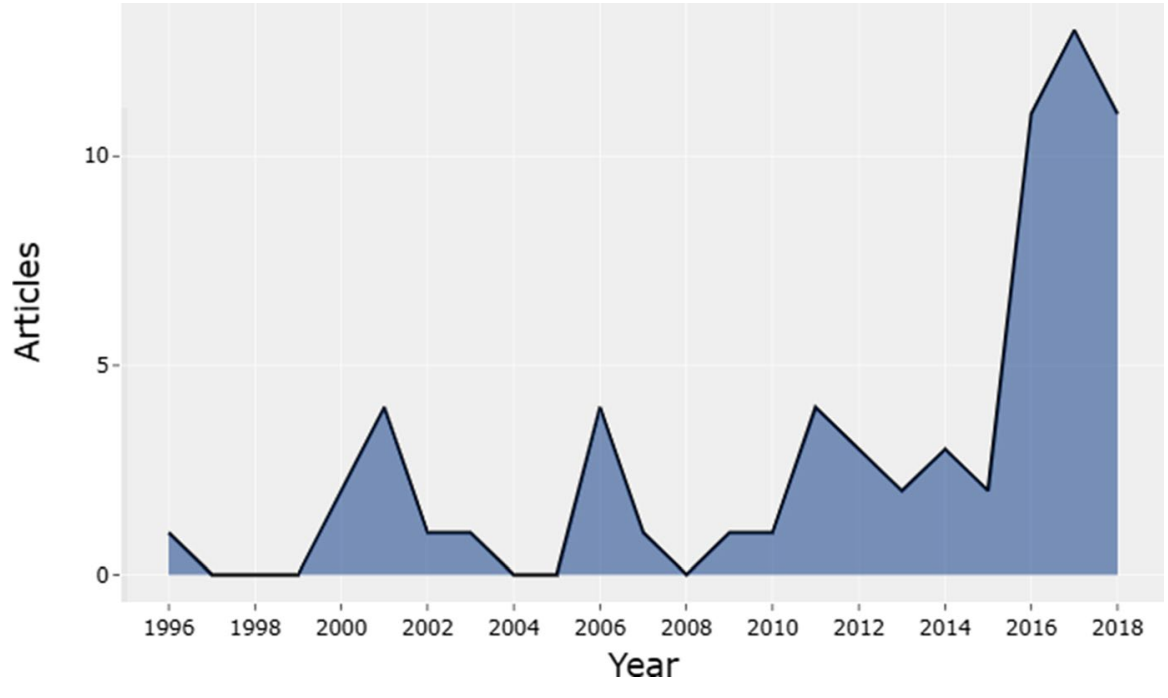

Fig. 2 Number of articles in each year

\section{Quantitative results}

\subsection{Historical development of the literature}

Figure 2 presents the historical development of papers on IDI and indicates the number of articles published each year between 1996 and April 2019.

As the figure shows, the number of published studies that simultaneously consider internationalization and digitalization has been growing over time since the first paper published by Lovelock and Yip in 1996. In particular, the number of articles per year grew from one in 1996 to 11 in 2018. The growing interest on the topic became particularly evident starting in 2005. As mentioned above, the various periods we have created are characterized by the same duration in terms of the number of years in all periods except one, where scarce production (i.e., number of yearly articles lower than one) leads us to use a longer period of reference. Our logic, inspired by previous review approaches (see Chabowski et al. 2011), found support in the content of each phase. In particular, each phase, as we report in the following paragraphs, was consistent in terms of thematic focus and presents specificities (see Table 4 on the most influential papers and Table 6 on the key patterns of the evolution of the four phases).

As shown in Fig. 2, the historical development of papers on IDI followed a nonlinear trend between 1996 and 2019. In particular, there are four peaks (2001, 2006, 2011, and 2017) that corroborate our temporal bracketing strategy. For the first period (1996-2004), there was a peak in production in 2001, when the Journal of International Business Studies published "E-Commerce and Global Business: The Impact of the Information and Communication Technology Revolution on the Conduct of International Business", which comprised different studies on IDI. 
Table 3 Number of articles in each journal

\begin{tabular}{lc}
\hline Journal & $\begin{array}{l}\text { Number } \\
\text { of articles }\end{array}$ \\
\hline Journal of International Business Studies & 12 \\
International Business Review & 10 \\
Journal of Business Research & 10 \\
Journal of World Business & 6 \\
Journal of International Management & 4 \\
Management International Review & 4 \\
California Management Review & 3 \\
Journal of Management Studies & 3 \\
Mit Sloan Management Review & 3 \\
European Management Journal & 2 \\
Journal of Management & 2 \\
Multinational Business Review & 2 \\
Academy of Management Journal & 1 \\
Asia Pacific Business Review & 1 \\
Business Horizons & 1 \\
Critical Perspectives on International Business & 1 \\
Harvard Business Review & 1 \\
Journal of Intellectual Capital & 1 \\
Management Decision & 1 \\
Total & \\
\hline & 1 \\
\hline
\end{tabular}

For the second period (2005-2009), we observed a stall of three years and then a peak in 2006, with practice-oriented papers focusing on IDI. For the third period (2010-2014), we observed a peak in 2011, probably due to the advent of the second generation of internet-based applications, or the so-called Fourth Industrial Revolution (Schwab 2016). More specifically, during those years, the diffusion of new technologies, such as social media, helped firms overcome distance and "facilitate interaction across geographic and psychological boundaries" (Alarcón-del-Amo et al. 2018, p. 356). Finally, for the fourth period (2015-2019), we observed a peak in 2017, undoubtedly boosted by the 2016 Journal of International Business Studies special issue, entitled "Internationalization in the Information Age", suggesting the importance of this debate in the international business literature. In conclusion, the development of the IDI literature is certainly not linear (i.e., characterized by the constant presence of peaks), and overall, these peaks have in part shaped the related debate, contributing to defining the content of each period, as will be explained in Sect. 5.

\subsection{Contributing journals and authors}

Table 3 reports the journals that mainly published articles on IDI. Notably, the four most frequent journals contributed to more than $50 \%$ of all the articles. The most 


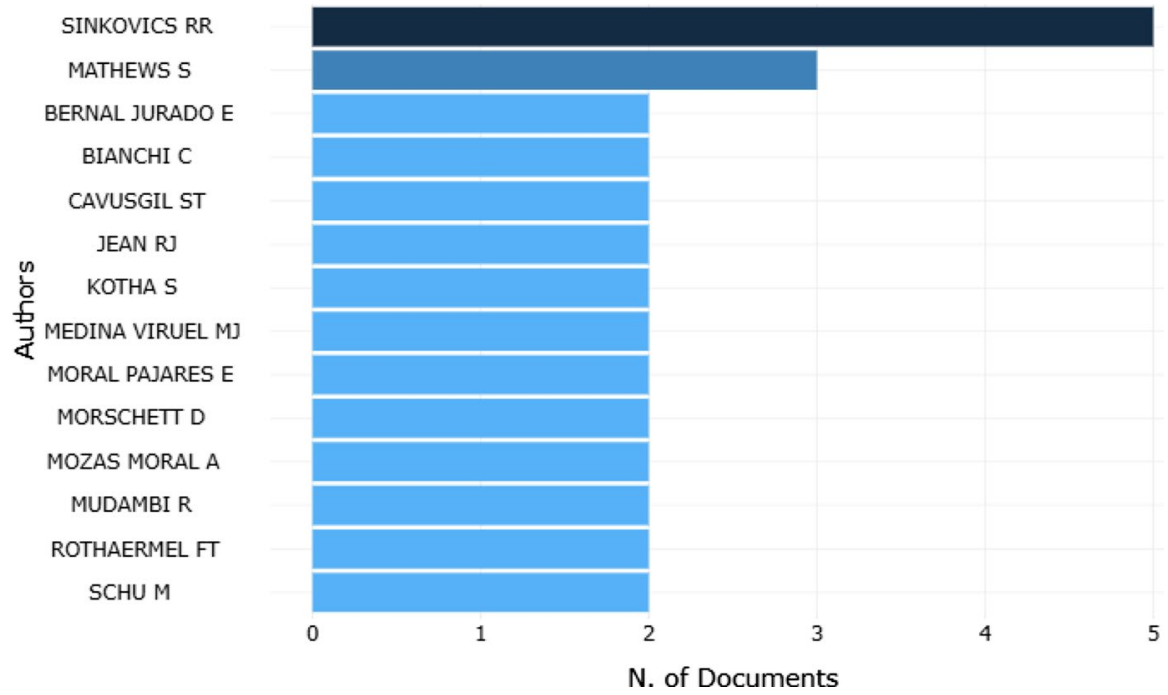

Fig. 3 List of authors that published two or more articles

productive journals were the Journal of International Business Studies and International Business Review (22 papers, 32\%). These publications were followed by two other journals: Journal of Business Research (10 papers, 15\%) and Journal of Word Business (6 papers, 9\%). MIT Sloan Management Review, as a journal for practitioners, has also played a relevant role in the affirmation of this topic.

A total of 162 authors approached internationalization and digitalization. Interestingly, our sample shows that seven scholars published documents authored by a single person, while 61 papers were authored by multiple people. Remarkably, only two authors wrote three or more papers. The bright side of this straightforward finding is that the literature on internationalization and digitalization is characterized by the perspectives of multiple authors. The dark side is that looking at the specialization level on the topic, there are very few distinct leading scholars, and the uncovered specialization may represent a drawback for future development.

Figure 3 provides a list of authors who published two or more papers.

\subsection{Most influential articles per period}

Table 4 shows the most influential papers in every step with the relative number of citations in the SSCI citation data files between 1996 and May 2019, accessed through the ISI Web of Science. The most influential papers belonging to the first period are certainly different in terms of background. They cover various themes but share the observation of IDI as an emerging phenomenon, mainly studying its strategic implications.

For example, Lovelock and Yip (1996) see information technology as a driver of globalization and define possible ways in which to identify global strategies for service businesses. Similarly, Prahalad and Ramaswamy (2000) consider how 


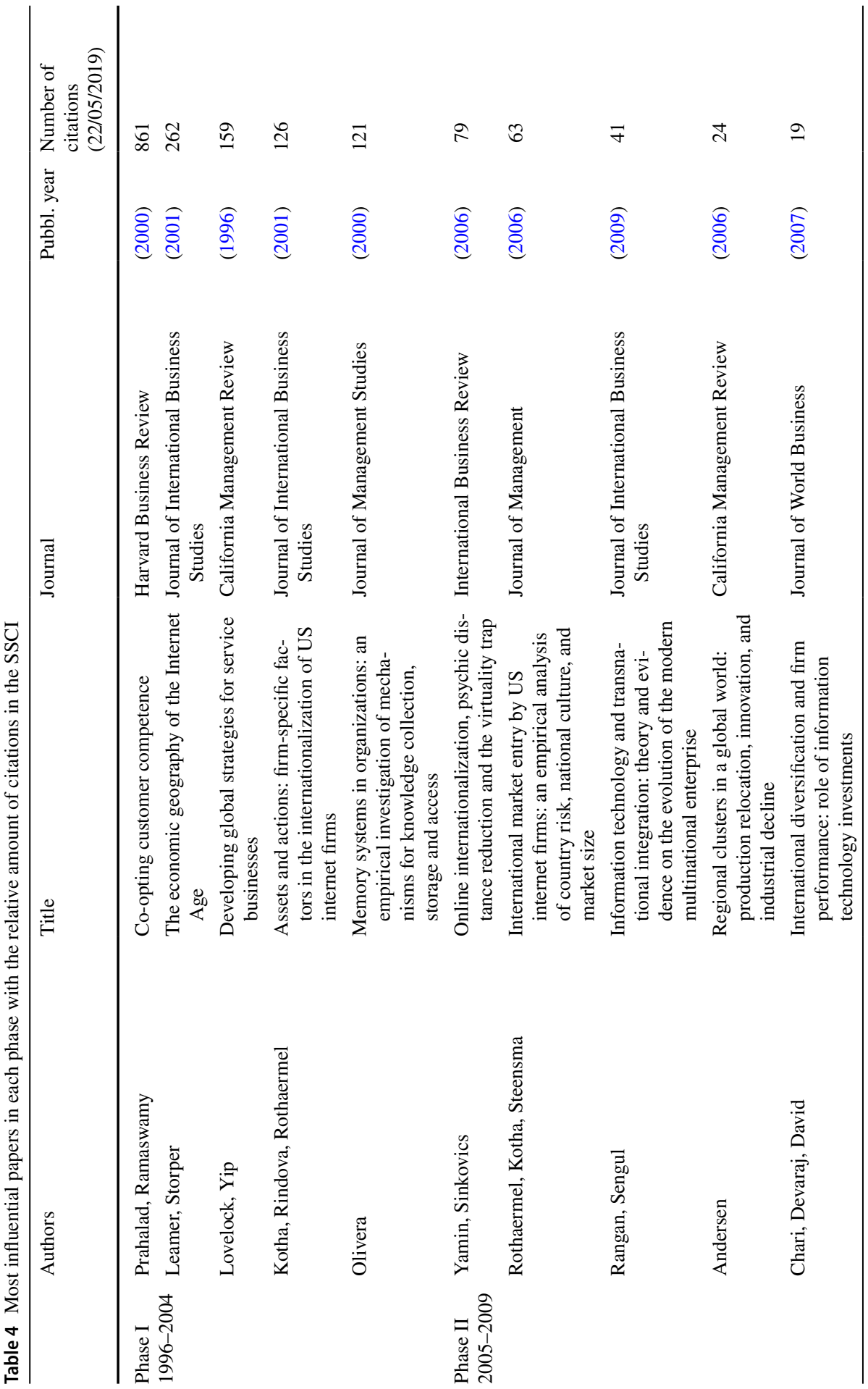




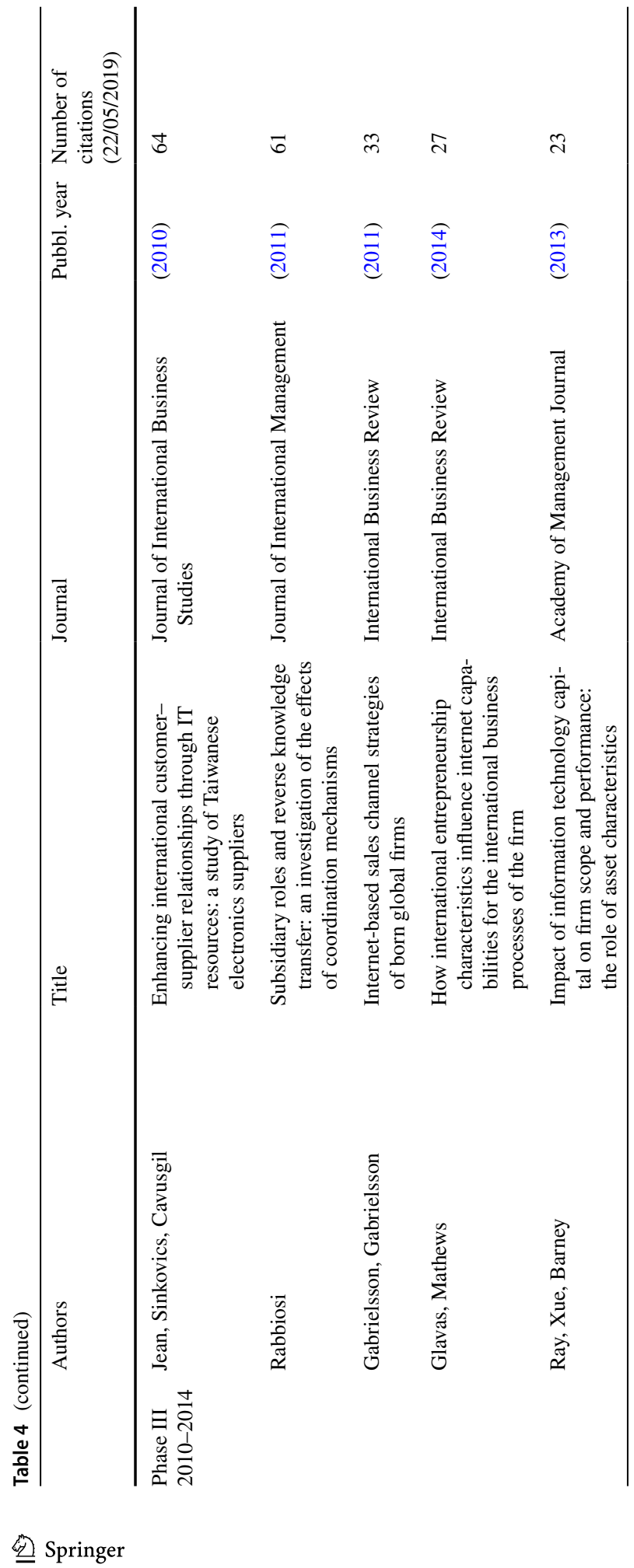




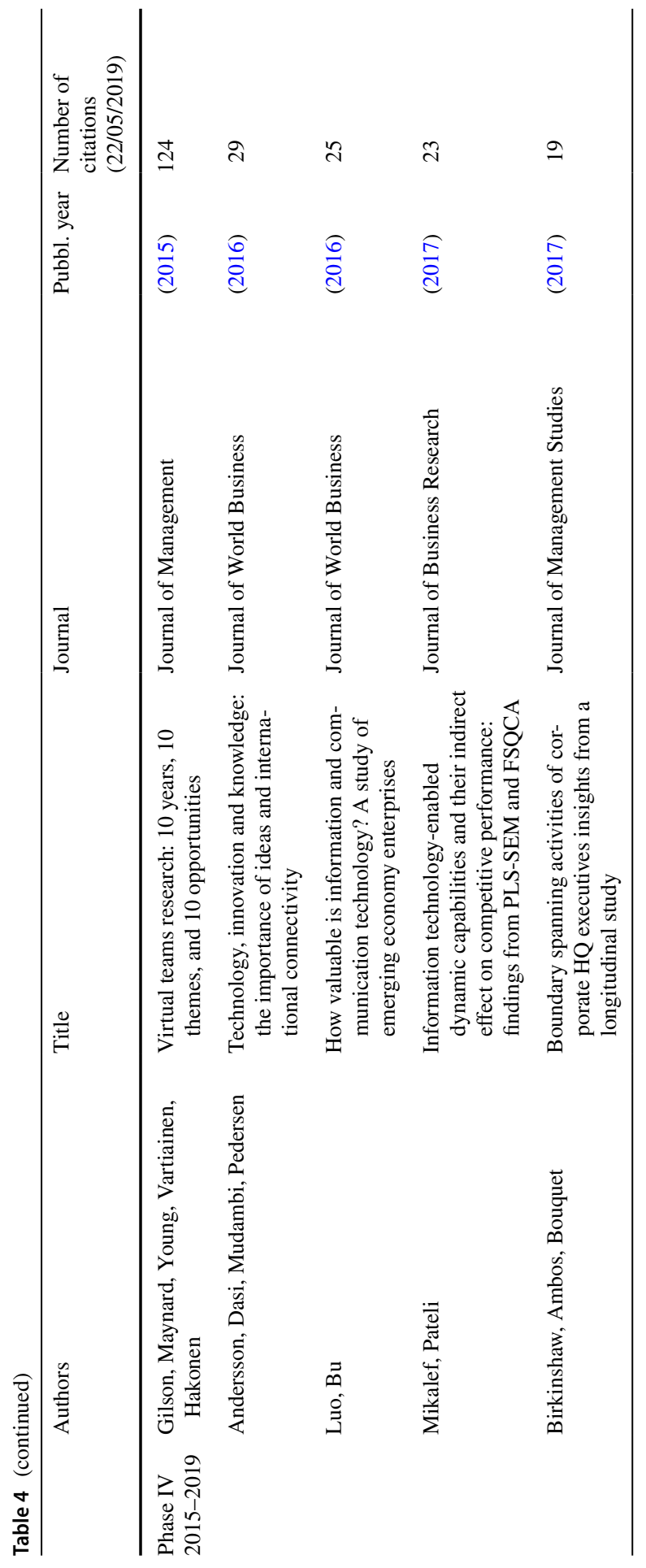


technological evolutions (particularly the internet) and globalization have determined the need to capture customer competence. Olivera (2000) studies computerbased systems to create internal memory systems for corporate experiential knowledge. Finally, Leamer and Storper (2001) explore the economic geography of the internet age, and Kotha et al. (2001) look at the specific factors (intangible assets and strategic activities) that foster the internationalization of internet firms.

Regarding the second period, the most influential articles seem to pay more attention to the costs and benefits of IDI. For example, Yamin and Sinkovic (2006) explore the role of the internet during the internationalization process and how it can reduce perceived psychic distance. Similarly, Rothaermel et al. (2006) focus on the country selection of internet firms and how this choice is based on balancing risk and returns. Andersen (2006) shows how digital value-added activities can affect production relocation in different regional clusters (Andersen 2006). Finally, Chari et al. (2007) demonstrate that investments in information technology are fundamental in enhancing the performance of international diversification, while Rangan and Sengul (2009) consider how such investments lead to a reduction in transaction and production costs.

In the third period, the most influential studies are mainly dedicated to understanding how digitalization can foster internationalization. In particular, Jean et al. (2010) explore how IT resources can enhance customer relationships in an international context, while Rabbiosi (2011) recognizes the role of internet-based channels as a tool to help born-global firms internationalize faster and reach new customers more easily. Gabrielsson and Gabrielsson (2011) identify, among others, electronicbased coordination mechanisms as useful tools for managing communication and knowledge transfer between foreign subsidiaries and headquarters. In the same vein, Glavas and Mathews (2014) find, among other things, that internet capabilities enable successful international performance.

Closer scrutiny of the most influential papers in the last period confirms what we saw in the third period, i.e., that studies on how digitalization fosters internationalization have been particularly well received. It is worth noting that two of the most cited papers are literature reviews dedicated to this aspect (Andersson et al. 2016; Gilson et al. 2015). Similarly, Mikalef and Pateli (2017) emphasize the importance of information and communication technology as a driver of dynamic capabilities and as a resource of competitive advantage in uncertain environments. Finally, Birkinshaw et al. (2017) analyze the boundary-spanning activities that allow virtual headquarters to make connections and, moreover, manage differences across the countries in which the subsidiaries are located.

\subsection{Structure of the domain}

As already mentioned, to understand the development of the literature and the structure of the research area, we analyzed the keywords that appear most frequently and occurrences per period. Figure 4 presents the major keywords listed in the papers. Among the macro keywords, 'context' is the most frequent (34\%) since the bulk of the literature is empirical and focused on specific contexts such as emerging 
markets, developing countries, and service industries. Most papers are associated with 'strategy/competitive advantage' (29\%) and 'ITC' (28\%). In the background, but certainly not overlooked, we can find the keywords 'internet', 'supply chain,' and 'knowledge'. A considerable proportion of articles consider the macro keywords 'psychic distance'2 (11\%), 'alliance/ties' (10\%), and 'entrepreneurship' (10\%), as well as 'social media/social network' (10\%) and 'network' (10\%). Interestingly, 'e-commerce' and 'export' do not occupy the first position in the ranking (10\% and $9 \%$, respectively). Indeed, as discussed in Sect. 2, the internationalization of channels is only one aspect related to internationalization.

Figure 5 provides an overview of major keywords and their relevance in time. We note that the macro keywords outline different trends over time. While the keyword 'context' generally assumes increasing relevance, 'internet' is notably the only keyword with a decreasing trend in recent years. We can also notice that the importance of the keyword 'e-commerce' has a fluctuating trend (higher in the first years, decreasing in the middle years, and slightly increasing in the last years).

With regard to the relevance of the various keywords in the four periods, as we previously noted, the macro keywords present some irregular patterns over all the periods (see Fig. 6).

In the first period (1996-2004), 'information and communication technology' and 'internet' seem to be the most relevant keywords and show an increasing trend. The same trend is followed by terms related to 'strategy and competitive advantage'. Conversely, we can see that the keyword 'e-commerce' appears only at the beginning of the 2000s.

In the second period (2005-2009), the keyword 'risk' assumes relevance, while 'information and communication technology' and 'strategy/competitive advantage' remain relatively consistent and stable. Conversely, we can see that the keyword 'network' emerges in this phase.

In the third period (2010-2014), certain keywords come to the forefront, such as 'entrepreneurship', 'capability', 'integration/coordination', 'control', and 'supply chain', which are the more innovative and frequent keywords in this phase. Conversely, terms such as 'strategy and competitive advantage', 'internet', and 'information and communication technology' remain relevant, even with a decreasing trend.

In the last period (2015-2019), 'supply chain', 'capability', 'strategy/competitive advantage' and 'psychic distance' remain relatively consistent. Among the emerging keywords, we can observe 'social media/social network', 'new digital technology/ industry 4.0 ', and 'knowledge'.

\footnotetext{
2 The macro keyword "psychic distance" includes all the elements of distance that can be defined as "the perceived differences between the characteristics of a firm's domestic environment and those of a foreign country" (Child et al. 2009, p. 209).
} 


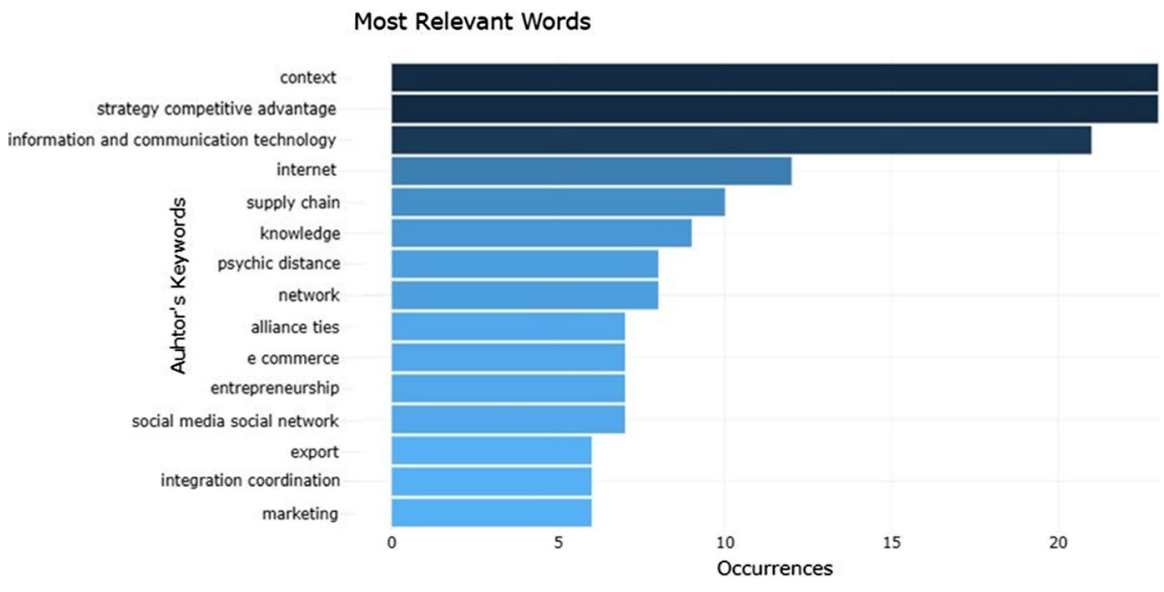

Fig. 4 Most relevant keywords

\section{Qualitative results}

\subsection{General overview of the methodological and theoretical background}

As Table 5 reports, our analysis indicates that 12 articles are mainly conceptual, 46 are empirical, seven are written by practitioners, and one is a research note. Interestingly, two articles are literature reviews (Andersson et al. 2016; Gilson et al. 2015): one focuses on the evolution of the concepts of knowledge, innovation, and technology in the international business literature (Andersson et al. 2016), and the other focuses on virtual teams' research, including the theme of globalization (Gilson et al. 2015).

Among the empirical papers, 13 take a qualitative research approach, 32 take a quantitative approach, and only one adopts a mixed qualitative-quantitative methodology. Therefore, the extant literature indicates a paucity of qualitative and mixed methods in approaching this topic.

Moreover, of the qualitative papers, only seven have an explicit longitudinal temporal dimension, while the others do not specify the temporal span of reference or are not longitudinal. Of the quantitative papers, 18 are cross-sectional, eight adopt a mixed perspective (i.e., partly observing the phenomena over time and partly not), and only six adopt a purely longitudinal perspective.

As you can see in Table 6, the theoretical approach of the papers is quite often not explicit (in 22 out of 68). The possible interpretation of this evidence is twofold. First, the rhetoric style in these studies is in good part more oriented toward presenting literature streams rather than theories, and second, the study of both digitalization and internationalization is a fairly new domain of study (Wright and Ricks 1994); as Vadana et al. (2019) suggest, despite everything, digital transformation has only begun. This may imply that scholars are hesitant to adopt predetermined theoretical views in their analyses. 


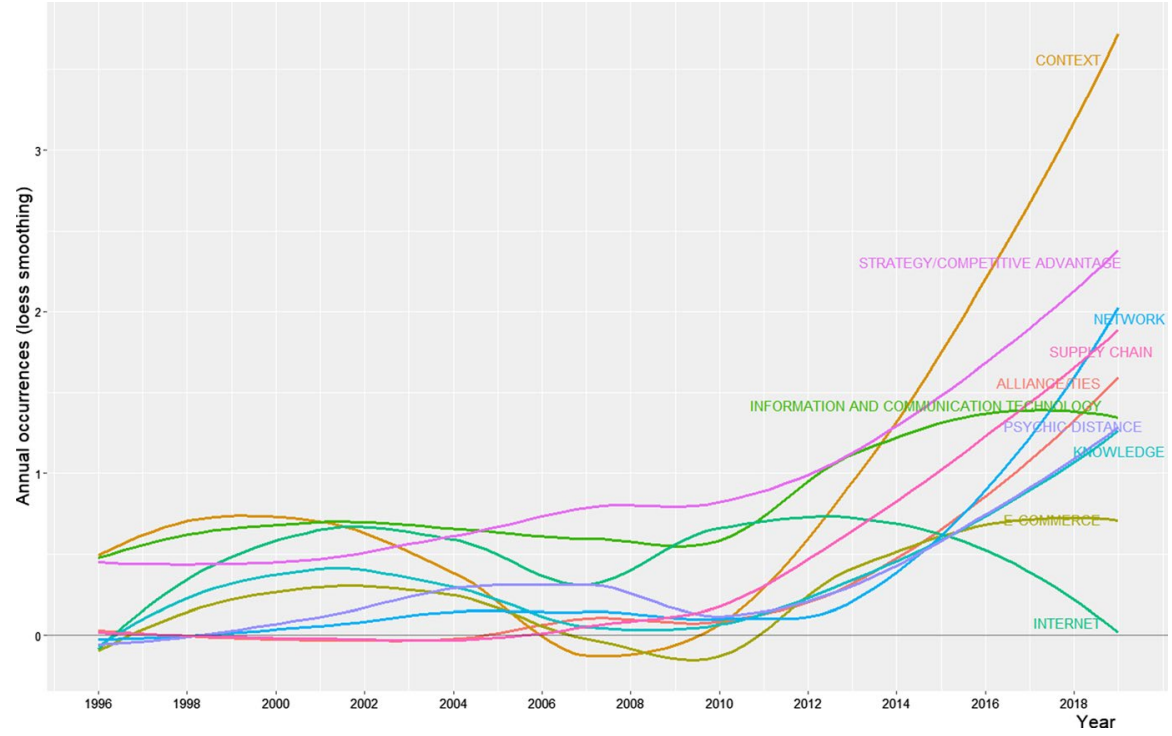

Fig. 5 Keywords occurrence over time

(a)

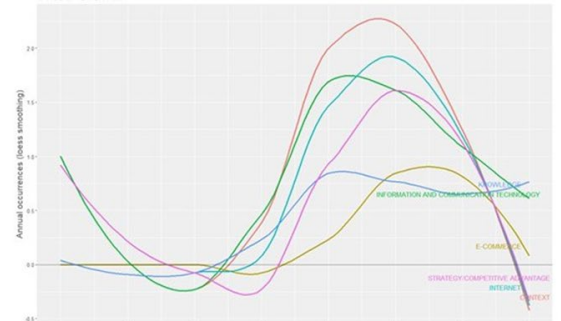

(c)

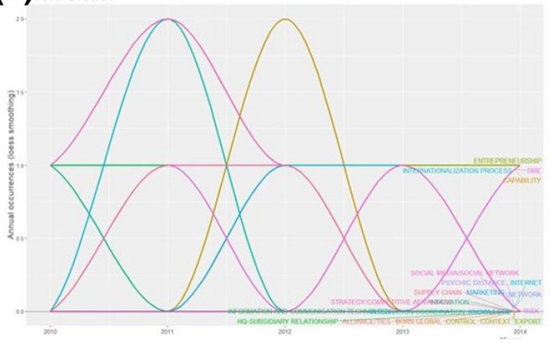

(b)

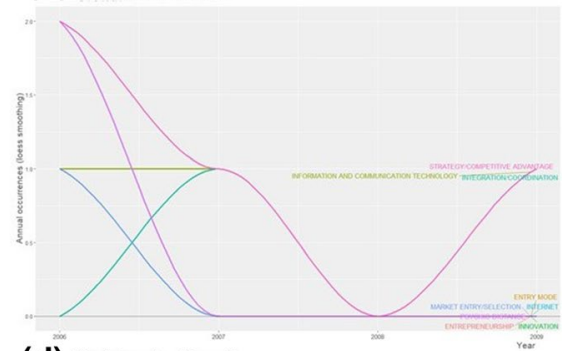

(d)

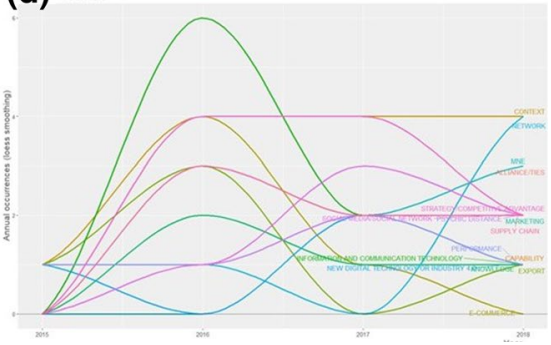

Fig. 6 Keywords occurrence in each phase

Among the papers with explicit theoretical approaches, we noted two interesting aspects. First, there was a tendency toward the adoption of multiple theories simultaneously (e.g., Ojala et al. 2018 and Sigfusson and Chetty 2013, which used network theory along with the resource-based view (RBV) and other perspectives 
Table 5 A picture of the research methods used

\begin{tabular}{|c|c|c|}
\hline $\begin{array}{l}\text { Type } \\
\text { (empirical\conceptual \literature } \\
\text { review) }\end{array}$ & $\begin{array}{l}\text { For empirical: METHOD } \\
\text { (qualitativelquantitativelmultiple } \\
\text { methods) }\end{array}$ & $\begin{array}{l}\text { Nature of the study } \\
\text { (cross-sectionalllongitudinal) }\end{array}$ \\
\hline \multirow[t]{5}{*}{46 empirical } & \multirow[t]{2}{*}{13 qualitatives } & 7 longitudinal \\
\hline & & 5 non explicit \\
\hline & \multirow[t]{3}{*}{32 quantitatives } & 18 cross-sectional \\
\hline & & 6 longitudinal \\
\hline & & 8 mixed \\
\hline \multicolumn{3}{|l|}{12 conceptual } \\
\hline \multicolumn{3}{|l|}{7 practitioners } \\
\hline \multicolumn{3}{|l|}{2 literature reviews } \\
\hline 1 research note & & \\
\hline
\end{tabular}

such as international entrepreneurship). Second, some papers relied more generally on the internationalization stream of the literature (and related groups of theories) rather than espousing a specific approach (e.g., Yamin and Sinkovics 2006).

Considering the principal research area, the vast majority of papers (54) presented are focused on internationalization, where the most popular theories were social network theory, transaction cost theory (TCE), the RBV, and the dynamic capabilities perspective. Internationalization was considered an outcome in the majority of cases (34); in such cases, it is interesting to note that digitalization was among the drivers in 20 cases, while it was a contextual element in eight of them. Internationalization played the role of a main driver in only two cases (here, digitalization was either a driver or moderator but never the outcome) and as a mediator or moderator in three cases. In eight cases, internationalization was seen purely as a contextual element. Finally, in four cases, internationalization (measured with different variables) was studied with some of its elements among moderators/mediators or drivers and some among outcomes. ${ }^{3}$

Only 14 papers had digitalization as a major research theme along with various subthemes. Unfortunately, in this case, the theoretical perspective was rarely explicitly declared, except for in four cases, of which one used the theory of disruption (Christensen 1997 in Alberti-Alhtaybat et al. 2019), and the other three used theories that had also prevailed in the other research areas (e.g., the RBV, TCE, and the dynamic capabilities perspective). Arguably, among these papers, digitalization was mainly seen as a driver, and only in one case was it seen as a contextual element (Prahalad and Ramaswamy 2000); no papers appear to have considered digitalization as an outcome or moderator/mediator. Therefore, our analysis revealed that in some papers, internationalization and digitalization were framed as complementing each other, while in others, one of the two concepts was instead used to build on the other. With regard to how internationalization and digitalization complement each

\footnotetext{
3 This classification was not possible for three papers because they were literature reviews or conceptual papers with no specific position regarding the role of internationalization.
} 


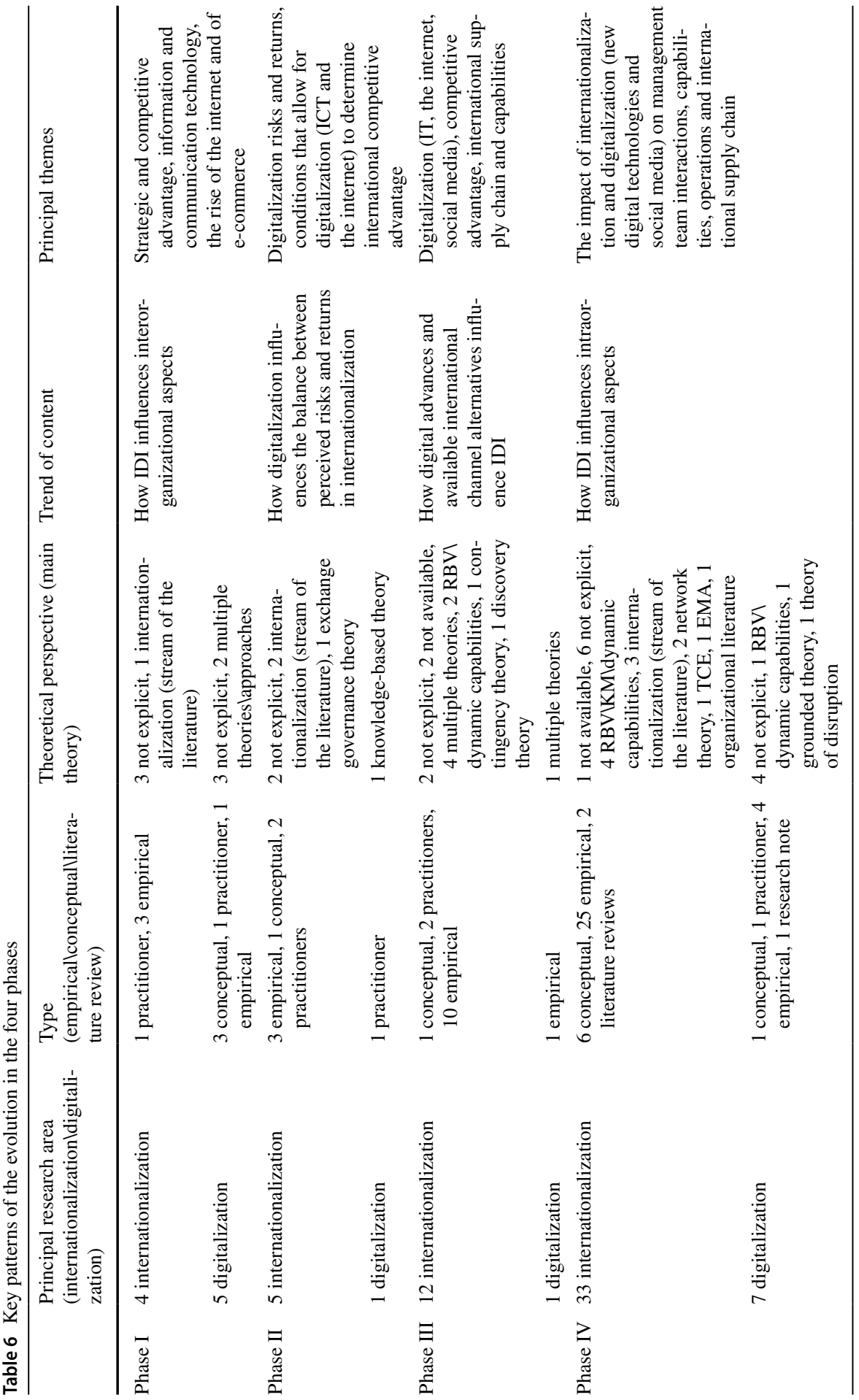


other, the findings were fairly consistent in representing a situation in which the various elements of digitalization had a positive interplay with internationalization (e.g., Bianchi and Mathews 2016; Kotha et al. 2001). Moreover, the debates that animated our sample papers also shed light on the ways in which internationalization and digitalization build on each other; in particular, we observed that in some cases, internationalization was the main topic and that digitalization was simply the context (e.g., Chen et al. 2019; Deng and Wang 2016; Rothaermel et al. 2006), while in others (slightly less frequent), internationalization was seen as a contextual element for the study of digitalization dynamics (e.g., Mikalef and Pateli 2017; Wentrup et al. 2019).

\subsection{A look at the evolution within the different periods of the methodological and theoretical background and content}

\subsubsection{Methodological and theoretical evolution}

The papers in our sample seem to have followed interesting paths. The literature on IDI has evolved in terms of the methods used, theoretical perspectives, and main findings relative to how internationalization and digitalization complement and build on each other. If we initially observed the emergence of a combination of papers adopting practitioner (e.g., Lovelock and Yip 1996) and conceptual (Leamer and Storper 2001) views, then as the debate developed, we also noted the growth of empirical papers and the application of more frequent qualitative and quantitative works. Thus, this domain seems to originate/be derived mainly from practitioner observations and conceptual efforts.

Internationalization and digitalization have also been approached from different theoretical perspectives and angles over time. Most likely following the natural evolution of these two phenomena, at first, scholars tended to rely on approaches traditionally used both in internationalization and digitalization research streams, such as the resource-based view (e.g., Kotha et al. 2001); in theories that were more representative of the management field, such as the dynamic capabilities theory (e.g., Sinkovics et al. 2011); or in the international business field, such as transaction cost economics (e.g., Ray et al. 2013) and, later, social network theory (Brouthers et al. 2016; Jeong 2016). As the discussions developed, the adoption of multiple perspectives simultaneously became more frequent, surely in recognition of the benefits obtainable with the integration/intersection of more lenses and angles to explain complex and intertwined phenomena such as internationalization and digitalization.

\subsubsection{Content evolution}

The content in our sample seems to have followed interesting paths during the four subperiods, consistent with the most influential papers for each phase.

The following are particularly worth noting:

Phase I (1996-2004): how IDI influences interorganizational aspects; 
Phase II (2005-2009): how digitalization influences the balancing between perceived risk and returns in internationalization;

Phase III (2010-2014): how digital advances and available internationalization channel alternatives influence IDI; and

Phase IV (2015-2019): how IDI influences intraorganizational aspects.

\subsection{Phase I}

During the first phase, in rapidly changing contexts dominated by technological change and globalization, the research focused on the themes of strategic choice and competitive advantage, information and communication technology, the internet, and e-commerce. In this period, constructs such as information and communication technology, the internet, and e-commerce are labeled 'digitalization', whereas internationalization is mainly framed in a broad sense through global strategies. Specifically, scholarly attention has been concentrated on the strategic shift that is needed in these contexts, where information technology is considered a helpful tool to obtain competitive advantages in different sectors such as those of service companies (Lovelock and Yip 1996) or business consulting companies (Olivera 2000). Overall, the scholarly focus seems to be mainly on interorganizational aspects such as interfirm transactions related to internationalization and technological innovations. In this vein, studies focus on how information and communication technology can facilitate commercial exchanges (Kotha et al. 2001; Singh and Kundu 2002), the exchange of knowledge and the creation of international trading networks among firms (Zaheer and Manrakhan 2001), or the possible effects of the internet on location decisions and firm interactions (Leamer and Storper 2001).

\subsection{Phase II}

During the second phase, the research focused on how digitalization influences the balancing between perceived risk and returns in internationalization and under what conditions digitalization affects international competitive advantage and performance. In this vein, for instance, Chari et al. (2007) recognize that investments in information technology support an effective process of international diversification, while Yamin and Sinkovics (2006) critically discuss how online internationalization reduces the perception of psychic distance.

Moreover, even if in this period, the research is still relatively focused on the interorganizational aspects of IDI, we witness the emergence of network as an additional way to refer to the concept of digitalization, whereas internationalization is mainly framed through specific foci such as exports, market entry selection, and entry modes. Thus, we can infer that this period is still relatively focused on the interorganizational aspects of IDI. 


\subsection{Phase III}

The third wave of the literature is more complex. We recognize three research paths. The first seems to represent an evolution of the previous phases and focuses on how organizational capabilities and processes influence the balance between perceived risk and returns in internationalization (Pezderka and Sinkovics 2011). The second research path focuses on how to manage organizational and interorganizational structures to gain an international competitive advantage. In this vein, Sinkovics et al. (2011, p. 193) argue that "the use of the integration through B2B information technology and trust can help MNEs to enhance local suppliers' responsiveness in global supply chain relationships". Moreover, Rabbiosi (2011) sheds light on the importance of finding a good combination between integration at the global level and necessary responsiveness at the local level. Accordingly, Zorzini et al. (2012) argue that cooperation along the supply chain is a necessary strategy underlying customer satisfaction, even if, as Gabrielsson and Gabrielsson (2011) argue, the development of small local channels and global channels have different goals, so the former plays a relevant role even if internet sales channels are implemented. Finally, a key topic in the first research path is the role of online social networks and internet capability in identifying entrepreneurial opportunities (Glavas and Mathews 2014; Sigfusson and Chetty 2013). The third research path argues that digitalization is a key variable affecting the governance of the international supply chain through cooperativeness, output monitoring, and behavior monitoring (Gloor and Giacomelli 2014; Kane et al. 2014; Jean et al. 2010).

\subsection{Phase IV}

The last period seems to place more emphasis on how IDI influences intraorganizational aspects, and while supply chains and capabilities remain in the vocabulary of these scholars, we observe the emergence of the theme of new digital technology or industry 4.0., which summarizes the concept of 'digitalization'. On the internationalization side, these aspects are mainly related to alliance ties, the supply chain, and different aspects of distance among countries, reflecting the current concerns related to the impact that new digital technologies will have on managing team interactions and firms' operations, capabilities, and knowledge. In detail, in this period, we identified two major lines of inquiry.

The first line of inquiry, which has at its center new digital technologies and/ or industry 4.0, seems to focus on how global players deal with/respond to the emergence of digital technologies (e.g., Alberti-Alhtaybat et al. 2019; Hannibal and Knight 2018; Strange and Zucchella 2017). Remarkably, a key focus is on the importance of collaborative knowledge management (Alberti-Alhtaybat et al. 2019) and on the knowledge processes that allow for interactions between macro and meso levels (nation, firm, and teams) and individual levels (Andersson et al. 2016). We also find papers that acknowledge the importance of virtual teams in globalization 
(Gilson et al. 2015). Conversely, some papers explore the critical role of the international supply chain and information technology in allowing firms to control, integrate, and consolidate their operations abroad (Gooris and Peeters 2016; Kim et al. 2018; Özcan et al. 2018). The nonempirical research developed in this period focuses on the effect of digitalization at more macro levels (Cano-Kollmann et al. 2018; Edwards et al. 2017), while the empirical research investigates the effects of digitalization on firm-level internationalization strategies (e.g., Wentrup et al. 2019) and analyzes the trust-building mechanisms that are implemented between the platform and its digital employees during entry into a foreign country. Ben-Ner and Siemsen (2017) study the effects of additive manufacturing (3D printing) on the location of multinational enterprises, while Vendrell-Herrero et al. (2018) focus on how digital-based firms internationalize their services and how foreign consumers react.

The second line of inquiry refers to the capabilities needed for internationalization in a context in which digital transformation is underway. Illustrative examples include the paper by Khanagha et al. (2018) on the capabilities of internationalized firms that allow them to respond to disruptive technologies (Khanagha et al. 2018), the paper by Mathews et al. (2016) on how internet marketing capabilities contribute to international growth (Mathews et al. 2016), or the paper by Mikalef and Pateli (2017) on how information-technology-enabled dynamic capabilities facilitate firms' agility, which in turn enhances the competitive performance of internationalized firms (Mikalef and Pateli 2017). In this group of papers, we also outline the focus on the role played by distance in the internationalization process of digital firms (Cheng and Yang 2017; Schu et al. 2016; Schu and Morschett 2017) in the specific case of digitalization in multisided markets (Ojala et al. 2018). Finally, social media practices in different cultural contexts (Lin et al. 2017) and their effects on internationalization and performance are also studied (Alarcón-del-Amo et al. 2018; Paniagua et al. 2017; Pogrebnyakov 2017).

\section{Discussion, research agenda and limitations}

\subsection{Discussion}

By conducting a structured assessment of the extant literature to answer our research questions (What is the structure of the IDI domain? How did the related research develop over time? What emerges that is of interest to practitioners and scholars studying this evolution? What are the future patterns of the research?), our work represents a first attempt to offer a clear overview of IDI, enrich the conversation about IDI, interpret its evolution, and provide an informative snapshot of this research domain. Moreover, this work represents a preliminary step in fostering common basic knowledge by disentangling the different meanings and concepts that have emerged (or disappeared) over time and can help researchers and Ph.D. students who want to read a structured research agenda on IDI and better position their studies in the previous literature. 
Regarding the structure of the IDI domain, we first reconstruct the origins and state of the art this domain and the debate in terms of journals, authors, themes, and theoretical and methodological approaches. Our research unveils a variety of key patterns and knowledge across research topics, theoretical developments, and methods.

Regarding the historical development of this research domain, we show that over the past 23 years analyzed, the evolution of the research on IDI assumed a relatively nonlinear form. IDI research has continued blossoming year after year and, especially today, is attracting the interest of a growing number of scholars. Remarkably, our literature review sheds light on the origins and evolutions involved in this debate. In particular, different endogenous factors have affected the development of this literature. In this regard, the evolution of digital technology is a crucial factor. Indeed, technology evolves over time, and digital advancement continues to reshape the business world and gives rise to new opportunities and disruptions across every industry (Schmidt and Cohen 2013).

Regarding the theoretical and methodological approaches used over time, our work unveils the heterogeneity of research approaches and recognizes the impressive expansion of the debate on IDI and its theoretical developments, revealing a continued variety of knowledge across research topics, theoretical developments, and methods over time.

Regarding the themes analyzed, as the keyword analysis shows, the debate on IDI is rather ductile and permeable with respect to the evolution of the two phenomena to which it refers (i.e., digitalization and internationalization). This characteristic shows a bright side: the IDI literature outlines a continuous and rapid evolution of terminology and concepts related to the theme. Nonetheless, there is also a dark side: the lack of a cumulative knowledge base leads to many difficulties in building a shared vocabulary and a cohesive scholarly community. Our paper is a preliminary step in fostering common basic knowledge, as it will help readers identify the fil rouge that connects the various contributions in our sampled articles along with their historical evolution. Our quantitative analysis also indicates that probably because of the breadth of the concept of digitalization, the debate in various cases quickly shifted from one aspect to another. Moreover, our qualitative analysis unveils four waves of content evolution that shifts from interorganizational aspects to intraorganizational aspects.

This development clearly shows how research follows the rapidly evolving dynamics of the IDI context. While this is certainly appreciable, it also implies that IDI scholars dedicate special attention to the effects of time on their research. Time and temporal fit are certainly key elements when designing research projects and interpreting the relative results, especially in IDI research (Ancona et al. 2001).

\subsection{Research agenda}

Our literature review allows us to identify underresearched aspects and provide ideas for future research that might advance conjunct analyses of internationalization and digitalization issues and increase the breadth of IDI studies. In particular, 
we suggest further integrating diverse theoretical perspectives and developing an understanding of how and why these two concepts are related. We also provide specific suggestions regarding possible perspectives, research design, and data analysis approaches that will be instrumental in bridging gap between the management and internationalization literature.

\subsubsection{Theoretical challenges}

First, the current IDI research is clearly weak in explaining "what causes what". Particularly, internationalization has been seen as a context, for example, considering multinational firms and their approaches to digitalization (e.g., Mikalef and Pateli 2017; Özcan et al. 2018; Schu et al. 2016), as a moderator (e.g., Luo and Bu 2016), or very often as an outcome, i.e., considering the benefits of digitalization for internationalization strategies (e.g., entry mode choices and market selection) (e.g., Chen and Kamal 2016; Mozas-Moral et al. 2016; Paniagua et al. 2017) and their success (Cheng and Yang 2017; Mathews et al. 2016; Peña-Vinces et al. 2012) but only very implicitly as a possible key driver of digitalization. Some possible hybrid frameworks of IDI (where the elements of digitalization and internationalization seem more intertwined and the traditional cause-effect approach is abandoned) have, however, begun to emerge (e.g., Molodchik and Jardon 2017). More research is needed to investigate digitalization and internationalization beyond causal relationships and to try to understand how internationalization can foster digitalization and how this relationship can be framed more like a dynamic intertwinement rather than a static cause-effect rapport.

Moreover, internationalization and digitalization were not studied as part of a circular process in any of the papers analyzed. This gap can stimulate scholars to increase their efforts in exploring IDI. In this respect, we suggest investigating whether IDI is always positive in nature: what are the drawbacks of digitalization during internationalization? For instance, what are the consequences of the information overload provided by digitalization? Is digitalization always good for international managers, or can it also cause stress, eventually increasing confusion and misunderstandings?

Second, some papers in our sample made an effort to envision the future of globalization and of internationalized firms in light of emerging digital innovations (e.g., Coviello et al. 2017; Parente et al. 2018; Strange and Zucchella 2017). Unfortunately, scant attention seems to have been paid to the developments that digitalization will present in the future as an answer to the needs and behaviors of multinational firms or as a consequence of evolutionary lines (in terms of location, supply chain, sustainable business models, etc.).

Third, we noted that the efforts toward classifying possible IDIs are often phenomena-driven, time-variant, or based on the data available, as opposed to being the consequence of rigorous theorizing. In addition, many different types of IDI exist. However, scholars often consider these types of IDI together, ignoring their uniqueness. In this vein, we suggest that rather than taking uniquely bivariate or multivariate approaches to examining IDI, taking a configurational approach (Meyer et al. 
1993) could be a solution for future studies. For example, configurations can be used in the future for a variety of dimensions of IDI to cluster them together, and conceptually driven typologies or empirically driven taxonomies can be produced.

Fourth, we noted the vast scholarly attention that has been paid to the role of the online channel as an essential mechanism linking digitalization to internationalization (Gabrielsson and Gabrielsson 2011; Glavas and Mathews 2014; Sigfusson and Chetty 2013). Thus far, the online channel has been seen as an information space where international opportunities are discovered. Despite the fact that this stream of the literature may appear to be at a mature stage, we note many important knowledge gaps. For instance, to what extent and how does this space also determine additional threats that hinder or damage the internationalization process (e.g., online security, online attacks, privacy, and risks of being copied)? How and why does the online interaction space affect the behaviors and perceptions of decision makers during the internationalization process? For example, what are the effects of interacting online (rather than physically) in group and personal interactions (e.g., interpersonal trust, communication, conflict, and negotiations) on the typical variables that explain internationalization decisions (e.g., cultural distance, institutional distance, geographic distance, etc.) and on the decisions themselves (e.g., investing in a new country, greenfield vs. brownfield, etc.)? Is the presence of an online transaction space always positive?

Finally, by leveraging the studies on digital advances and the available internationalization channel alternatives, we call for new studies focused on how the integration space facilitates resource acquisition and online social capital development (e.g., Gabrielsson and Kirpalani 2004; Sigfusson and Chetty 2013). Specifically, future research should investigate (a) the durability of such resources and social capital in the competitive environment, (b) the characteristics of online social capital compared to those of traditional capital, and (c) the implications of such characteristics for the implementation of internationalization strategies.

\subsubsection{Methodological challenges}

As reported above, IDI research has been characterized by a decent extent of methodological diversity. In particular, the proportions of quantitative and qualitative approaches may offer the opportunity to reduce this asymmetry. While qualitative methods may imply relying on subjective data and high investments for gathering and analyzing information, future research may consider following this type of approach to shed more light on the dynamics that quantitative studies may not capture (Zolfagharian et al. 2018). In addition, considering the complex nature of this research domain, a combination of qualitative and quantitative studies may allow us to produce a more precise and reliable comprehension of the dynamics studied.

Moreover, we suggest continuing to invest in longitudinal studies to correctly consider the temporal characteristics of the relationship between internationalization and digitalization. This implies that more empirical research from longitudinal perspectives, i.e., data gathering that is aimed at observing the evolution of the phenomenon over time, is recommended to enrich this literature with deeper insights (Certo et al. 2017). 
Furthermore, our review has shown that the conceptual development of IDI research is still ongoing, and the many aspects and subdimensions related to IDI make it virtually impossible to propose a clear list of all the possible variables and measurements that can be used in IDI research. Nevertheless, we hope that with our work, we have facilitated the creation of a common vocabulary and reiterate our call for research in which key concepts are explicitly defined and clearly measured to minimize confusion.

Finally, future reviews should include additional types of journals and may also include academic books and consultancy reports to highlight their influence on the development of this domain. Nevertheless, we trust that our review has identified the key traits of the IDI debate.

\subsection{Limitations}

While our review highlights some stimulating insights, there are various limitations that we hope future works will overcome. Despite our effort to offer a comprehensive review, our review is still limited by the selection strategy followed, which may have shaped the results of our review. We believe that one limitation is the number of articles we reviewed and the exclusion of papers published in other journals beyond those in international business and management. For instance, our literature review overlooked other relevant discipline backgrounds, such as finance, accounting, and information systems. We acknowledge that by following such an approach, we examined a considerable but specific segment of the literature. We recognize that other disciplines have also investigated these two phenomena that need to be analyzed in depth; therefore, we call for future studies to provide additional insight by combining different disciplinary backgrounds for understanding IDI.

Second, in terms of the quantitative analysis of the literature (such as the keyword analysis), although it guarantees a good level of objectivity and neutrality vis-à-vis authors' perspectives (Nerur et al. 2008; Zupic and Čater 2015), the understanding of such analyses is subject to the interpretation bias of the authors. However, we certify our commitment and effort to lessen this bias. Indeed, separately and jointly, in multiple ways and at various times, we have repetitively verified our results by comparing our analyses of the literature with those of other authors.

Acknowledgements The authors would like to thank Prof. Corrado Cuccurullo for his help with the coding of the data

Funding Open access funding provided by Università degli Studi di Bergamo within the CRUI-CARE Agreement.

Open Access This article is licensed under a Creative Commons Attribution 4.0 International License, which permits use, sharing, adaptation, distribution and reproduction in any medium or format, as long as you give appropriate credit to the original author(s) and the source, provide a link to the Creative Commons licence, and indicate if changes were made. The images or other third party material in this article are included in the article's Creative Commons licence, unless indicated otherwise in a credit line to the material. If material is not included in the article's Creative Commons licence and your intended use is not permitted by statutory regulation or exceeds the permitted use, you will need to obtain permission directly from the copyright holder. To view a copy of this licence, visit http://creativecommons.org/licen ses/by/4.0/. 


\section{Appendix 1: List of Academic Journals}

\section{Field: Management}

Ranking: 4* and 4

Academy of Management Journal

Academy of Management Review

Administrative Science Quarterly

Journal of Management

Academy of Management Annals

British Journal of Management

Journal of Management Studies

Ranking: 3

Academy of Management Perspectives

Business and Society

California Management Review

European Management Review

Harvard Business Review

International Journal of Management Reviews

Journal of Business Research

Journal of Management Inquiry

MIT Sloan Management Review

Ranking: 2

Africa Journal of Management

Australian Journal of Management

Business and Politics

Business Ethics: A European Review

Business Horizons

Canadian Journal of Administrative Sciences

Competition and Change

European Business Review

European Journal of Women's Studies

European Management Journal

Feminist Economics

Feminist Review

IIM Kozhikode Society \& Management Review

International Journal of Business Governance and Ethics

International Journal of Gender and Entrepreneurship

International Studies of Management and Organization

Journal of General Management

Journal of Intellectual Capital

Journal of Management \& Organization

Journal of Revenue and Pricing Management

Management Decision

Management Revue: Socio-economic Studies

Review of Managerial Science

Scandinavian Journal of Management

Schmalenbach Business Review

Sex Roles

Signs
Field: International Business

Ranking: 4* and 4

Journal of International Business Studies

Journal of World Business (formerly Columbia JWB)

Ranking: 3

African Affairs

Asia Pacific Journal of Management

International Business Review

Journal of Common Market Studies

Journal of International Management

Management and Organization Review

Management International Review

Ranking: 2

Asia Pacific Business Review

Asian Business and Management

China Quarterly

Critical Perspectives on International Business

Cross Cultural \& Strategic Management

Emerging Markets Review

Eurasian Geography and Economics

Europe-Asia Studies

Global Networks

Journal of Business Economics and Management

Journal of Latin American Studies

Journal of Modern African Studies

Journal of World Trade

Multinational Business Review

Review of African Political Economy

Third World Quarterly

Thunderbird International Business Review

Transnational Corporations 


\section{Appendix 2: List of 68 articles in the sample}

\begin{tabular}{|c|c|c|c|}
\hline Authors & Title & Journal & Pubbl. year \\
\hline $\begin{array}{l}\text { Alarcón-del-Amo, } \\
\text { Rialp-Criado, Rialp-Criado }\end{array}$ & $\begin{array}{l}\text { Examining the Impact of } \\
\text { Managerial Involvement } \\
\text { with Social Media on } \\
\text { Exporting Firm Perfor- } \\
\text { mance }\end{array}$ & $\begin{array}{l}\text { International Business } \\
\text { Review }\end{array}$ & (2018) \\
\hline $\begin{array}{l}\text { Alberti-Alhtaybat, } \\
\text { Al-Htaybat, Hutaibat }\end{array}$ & $\begin{array}{l}\text { A Knowledge Management } \\
\text { and Sharing Business } \\
\text { Model for Dealing with } \\
\text { Disruption: the Case of } \\
\text { Aramex }\end{array}$ & $\begin{array}{l}\text { Journal of Business } \\
\text { Research }\end{array}$ & (2019) \\
\hline Andersen & $\begin{array}{l}\text { Regional Clusters in a } \\
\text { Global World: Production } \\
\text { Relocation, Innovation, } \\
\text { and Industrial Decline }\end{array}$ & $\begin{array}{l}\text { California Management } \\
\text { Review }\end{array}$ & (2006) \\
\hline $\begin{array}{l}\text { Andersson, Dasi, Mudambi, } \\
\text { Pedersen }\end{array}$ & $\begin{array}{l}\text { Technology, Innovation } \\
\text { and Knowledge: The } \\
\text { Importance of Ideas and } \\
\text { International Connectivity }\end{array}$ & Journal of World Business & (2016) \\
\hline Ben-Ner, Siemsen & $\begin{array}{l}\text { Decentralization and Locali- } \\
\text { zation of Production: } \\
\text { the Organizational and } \\
\text { Economic Consequences } \\
\text { of Additive Manufacturing } \\
\text { (3D Printing) }\end{array}$ & $\begin{array}{l}\text { California Management } \\
\text { Review }\end{array}$ & $(2017)$ \\
\hline Bianchi, Mathews & $\begin{array}{l}\text { Internet Marketing and } \\
\text { Export Market Growth in } \\
\text { Chile }\end{array}$ & $\begin{array}{l}\text { Journal of Business } \\
\text { Research }\end{array}$ & (2016) \\
\hline Birkinshaw, Ambos, Bouquet & $\begin{array}{l}\text { Boundary Spanning } \\
\text { Activities of Corporate HQ } \\
\text { Executives Insights From a } \\
\text { Longitudinal Study }\end{array}$ & $\begin{array}{l}\text { Journal of Management } \\
\text { Studies }\end{array}$ & $(2017)$ \\
\hline Brouthers, Geisser, Rothlauf & $\begin{array}{l}\text { Explaining the Internation- } \\
\text { alization of I-Business } \\
\text { Firms }\end{array}$ & $\begin{array}{l}\text { Journal of International } \\
\text { Business Studies }\end{array}$ & (2016) \\
\hline $\begin{array}{l}\text { Cano-Kollmann, Hannigan, } \\
\text { Mudambi }\end{array}$ & $\begin{array}{l}\text { Global Innovation Net- } \\
\text { works-Organizations and } \\
\text { People }\end{array}$ & $\begin{array}{l}\text { Journal of International } \\
\text { Management }\end{array}$ & (2018) \\
\hline Chari, Devaraj, David & $\begin{array}{l}\text { International Diversification } \\
\text { and Firm Performance: } \\
\text { Role of Information Tech- } \\
\text { nology Investments }\end{array}$ & Journal of World Business & (2007) \\
\hline Chen, Kamal & $\begin{array}{l}\text { The Impact of Informa- } \\
\text { tion and Communication } \\
\text { Technology Adoption on } \\
\text { Multinational Firm Bound- } \\
\text { ary Decisions }\end{array}$ & $\begin{array}{l}\text { Journal of International } \\
\text { Business Studies }\end{array}$ & (2016) \\
\hline
\end{tabular}




\begin{tabular}{|c|c|c|c|}
\hline Authors & Title & Journal & Pubbl. year \\
\hline Chen, Shaheer, Yi, Li & $\begin{array}{l}\text { The International Penetration } \\
\text { of Ibusiness Firms: Net- } \\
\text { work Effects, Liabilities of } \\
\text { Outsidership and Country } \\
\text { Clout }\end{array}$ & $\begin{array}{l}\text { Journal of International } \\
\text { Business Studies }\end{array}$ & $\begin{array}{l}(2019) \\
\end{array}$ \\
\hline Cheng, Yang & $\begin{array}{l}\text { Enhancing Performance of } \\
\text { Cross-Border Mergers and } \\
\text { Acquisitions in Developed } \\
\text { Markets: the Role of Busi- } \\
\text { ness Ties and Technologi- } \\
\text { cal Innovation Capability }\end{array}$ & $\begin{array}{l}\text { Journal of Business } \\
\text { Research }\end{array}$ & (2017) \\
\hline Coviello, Kano, Liesch & $\begin{array}{l}\text { Adapting the Uppsala } \\
\text { Model to a Modern World: } \\
\text { Macro-Context and Micro- } \\
\text { foundations }\end{array}$ & $\begin{array}{l}\text { Journal of International } \\
\text { Business Studies }\end{array}$ & (2017) \\
\hline Deng, Wang & $\begin{array}{l}\text { Early-Mover Advantages at } \\
\text { Cross-Border Business- } \\
\text { To-Business E-Commerce } \\
\text { Portals }\end{array}$ & $\begin{array}{l}\text { Journal of Business } \\
\text { Research }\end{array}$ & (2016) \\
\hline $\begin{array}{l}\text { Edwards, Pärn, Love, El- } \\
\text { Gohary }\end{array}$ & $\begin{array}{l}\text { Research Note: Machinery, } \\
\text { Manumission, and Eco- } \\
\text { nomic Machinations }\end{array}$ & $\begin{array}{l}\text { Journal of Business } \\
\text { Research }\end{array}$ & (2017) \\
\hline Gabrielsson, Gabrielsson & $\begin{array}{l}\text { Internet-Based Sales Chan- } \\
\text { nel Strategies of Born } \\
\text { Global Firms }\end{array}$ & $\begin{array}{l}\text { International Business } \\
\text { Review }\end{array}$ & (2011) \\
\hline $\begin{array}{l}\text { Gilson, Maynard, Young, } \\
\text { Vartiainen, Hakonen }\end{array}$ & $\begin{array}{l}\text { Virtual Teams Research: } 10 \\
\text { Years, } 10 \text { Themes, and } 10 \\
\text { Opportunities }\end{array}$ & Journal of Management & $(2015)$ \\
\hline Glavas, Mathews & $\begin{array}{l}\text { How International Entrepre- } \\
\text { neurship Characteristics } \\
\text { Influence Internet Capa- } \\
\text { bilities for the International } \\
\text { Business Processes of the } \\
\text { Firm }\end{array}$ & $\begin{array}{l}\text { International Business } \\
\text { Review }\end{array}$ & (2014) \\
\hline $\begin{array}{l}\text { Globerman, Roehl, Stan- } \\
\text { difird }\end{array}$ & $\begin{array}{l}\text { Globalization and Electronic } \\
\text { Commerce: Inferences } \\
\text { from Retail Brokering }\end{array}$ & $\begin{array}{l}\text { Journal of International } \\
\text { Business Studies }\end{array}$ & (2001) \\
\hline Gloor, Giacomelli & $\begin{array}{l}\text { Reading Global Clients' } \\
\text { Signals }\end{array}$ & $\begin{array}{l}\text { Mit Sloan Management } \\
\text { Review }\end{array}$ & (2014) \\
\hline Goerzen & $\begin{array}{l}\text { Small Firm Boundary- } \\
\text { Spanning Via Bridging } \\
\text { Ties: Achieving Interna- } \\
\text { tional Connectivity Via } \\
\text { Cross-Border Inter-Cluster } \\
\text { Alliances }\end{array}$ & $\begin{array}{l}\text { Journal of International } \\
\text { Management }\end{array}$ & (2018) \\
\hline Gooris, Peeters & $\begin{array}{l}\text { Fragmenting Global } \\
\text { Business Processes: a } \\
\text { Protection for Proprietary } \\
\text { Information }\end{array}$ & $\begin{array}{l}\text { Journal of International } \\
\text { Business Studies }\end{array}$ & (2016) \\
\hline
\end{tabular}




\begin{tabular}{|c|c|c|c|}
\hline Authors & Title & Journal & Pubbl. year \\
\hline Hannibal, Knight & $\begin{array}{l}\text { Additive Manufacturing } \\
\text { and the Global Factory: } \\
\text { Disruptive Technologies } \\
\text { and the Location of Inter- } \\
\text { national Business }\end{array}$ & $\begin{array}{l}\text { International Business } \\
\text { Review }\end{array}$ & $(2018)$ \\
\hline $\begin{array}{l}\text { Javalgi, Todd, Johnston, } \\
\text { Granot }\end{array}$ & $\begin{array}{l}\text { Entrepreneurship, Mud- } \\
\text { dling Through, and Indian } \\
\text { Internet-Enabled SMEs }\end{array}$ & $\begin{array}{l}\text { Journal of Business } \\
\text { Research }\end{array}$ & (2012) \\
\hline Jean, Sinkovics, Cavusgil & $\begin{array}{l}\text { Enhancing International } \\
\text { Customer-Supplier } \\
\text { Relationships Through } \\
\text { IT Resources: a Study of } \\
\text { Taiwanese Electronics } \\
\text { Suppliers }\end{array}$ & $\begin{array}{l}\text { Journal of International } \\
\text { Business Studies }\end{array}$ & (2010) \\
\hline Jeong & $\begin{array}{l}\text { Types of Foreign Networks } \\
\text { and Internationalization } \\
\text { Performance of Korean } \\
\text { SMEs }\end{array}$ & $\begin{array}{l}\text { Multinational Business } \\
\text { Review }\end{array}$ & (2016) \\
\hline Kane, Palmer, Phillips, Kiron & $\begin{array}{l}\text { Finding the Value in Social } \\
\text { Business }\end{array}$ & $\begin{array}{l}\text { Mit Sloan Management } \\
\text { Review }\end{array}$ & $(2014)$ \\
\hline $\begin{array}{l}\text { Khanagha, Zadeh, } \\
\text { Mihalache, Volberda }\end{array}$ & $\begin{array}{l}\text { Embracing Bewilderment: } \\
\text { Responding to Tech- } \\
\text { nological Disruption in } \\
\text { Heterogeneous Market } \\
\text { Environments }\end{array}$ & $\begin{array}{l}\text { Journal of Management } \\
\text { Studies }\end{array}$ & $(2018)$ \\
\hline Kim, Jean, Sinkovics & $\begin{array}{l}\text { Drivers of Virtual Interfirm } \\
\text { Integration and Its Impact } \\
\text { on Performance in Interna- } \\
\text { tional Customer-Supplier } \\
\text { Relationships }\end{array}$ & $\begin{array}{l}\text { Management International } \\
\text { Review }\end{array}$ & $(2018)$ \\
\hline Kotha, Rindova, Rothaermel & $\begin{array}{l}\text { Assets and Actions: Firm- } \\
\text { Specific Factors in the } \\
\text { Internationalization of US } \\
\text { Internet Firms }\end{array}$ & $\begin{array}{l}\text { Journal of International } \\
\text { Business Studies }\end{array}$ & (2001) \\
\hline Lagerström, Andersson & $\begin{array}{l}\text { Creating and Sharing } \\
\text { Knowledge within a } \\
\text { Transnational Team-The } \\
\text { Development of a Global } \\
\text { Business System }\end{array}$ & Journal of World Business & (2003) \\
\hline Leamer, Storper & $\begin{array}{l}\text { The Economic Geography of } \\
\text { the Internet Age }\end{array}$ & $\begin{array}{c}\text { Journal of International } \\
\text { Business Studies }\end{array}$ & (2001) \\
\hline Lee, Oh, Lee & $\begin{array}{l}\text { The Effect of Host Country } \\
\text { Internet Infrastructure } \\
\text { on Foreign Expansion of } \\
\text { Korean MNCs }\end{array}$ & $\begin{array}{l}\text { Asia Pacific Business } \\
\text { Review }\end{array}$ & (2017) \\
\hline Lin, Swarna, Bruning & $\begin{array}{l}\text { Taking a Global View on } \\
\text { Brand Post Popularity: } \\
\text { Six Social Media Brand } \\
\text { Post Practices for Global } \\
\text { Markets }\end{array}$ & Business Horizons & (2017) \\
\hline Lovelock, Yip & $\begin{array}{l}\text { Developing Global Strate- } \\
\text { gies for Service Businesses }\end{array}$ & $\begin{array}{l}\text { California Management } \\
\text { Review }\end{array}$ & (1996) \\
\hline
\end{tabular}




\begin{tabular}{|c|c|c|c|}
\hline Authors & Title & Journal & Pubbl. year \\
\hline$\overline{\text { Luo, } \mathrm{Bu}}$ & $\begin{array}{l}\text { How Valuable Is Informa- } \\
\text { tion and Communication } \\
\text { Technology? A Study } \\
\text { of Emerging Economy } \\
\text { Enterprises }\end{array}$ & Journal of World Business & $(2016)$ \\
\hline $\begin{array}{r}\text { Mathews, Bianchi, Perks, } \\
\text { Healy, Wickramasekera }\end{array}$ & $\begin{array}{l}\text { Internet Marketing Capa- } \\
\text { bilities and International } \\
\text { Market Growth }\end{array}$ & $\begin{array}{l}\text { International Business } \\
\text { Review }\end{array}$ & (2016) \\
\hline Mikalef, Pateli & $\begin{array}{l}\text { Information Technology- } \\
\text { Enabled Dynamic Capa- } \\
\text { bilities and Their Indirect } \\
\text { Effect on Competitive Per- } \\
\text { formance: Findings from } \\
\text { PLS-SEM And FSQCA }\end{array}$ & $\begin{array}{l}\text { Journal of Business } \\
\text { Research }\end{array}$ & (2017) \\
\hline Molodchik, Jardon & $\begin{array}{l}\text { Intellectual Capital as } \\
\text { Enhancer of Product Nov- } \\
\text { elty an Empirical Study } \\
\text { of Russian Manufacturing } \\
\text { SMEs }\end{array}$ & $\begin{array}{l}\text { Journal of Intellectual } \\
\text { Capital }\end{array}$ & (2017) \\
\hline $\begin{array}{l}\text { Montoro-Sanchez, Diez-Vial, } \\
\text { Belso-Martinez }\end{array}$ & $\begin{array}{l}\text { The Evolution of The } \\
\text { Domestic Network Con- } \\
\text { figuration as a Driver of } \\
\text { International Relationships } \\
\text { In SMEs }\end{array}$ & $\begin{array}{l}\text { International Business } \\
\text { Review }\end{array}$ & $(2018)$ \\
\hline $\begin{array}{l}\text { Moral-Pajares, Mozas- } \\
\text { Moral, Bernal-Jurado, } \\
\text { Medina-Viruel }\end{array}$ & $\begin{array}{l}\text { Efficiency and Exports: } \\
\text { Evidence from Southern } \\
\text { European Companies }\end{array}$ & $\begin{array}{l}\text { Journal of Business } \\
\text { Research }\end{array}$ & $(2015)$ \\
\hline $\begin{array}{l}\text { Mozas-Moral, Moral- } \\
\text { Pajares, Medina-Viruel, } \\
\text { Bernal-Jurado }\end{array}$ & $\begin{array}{l}\text { Manager's Educational } \\
\text { Background and ICT Use } \\
\text { as Antecedents of Export } \\
\text { Decisions: a Crisp Set } \\
\text { QCA Analysis }\end{array}$ & $\begin{array}{l}\text { Journal of Business } \\
\text { Research }\end{array}$ & (2016) \\
\hline Ojala, Evers, Rialp & $\begin{array}{l}\text { Extending the International } \\
\text { New Venture Phenomenon } \\
\text { to Digital Platform Provid- } \\
\text { ers: a Longitudinal Case } \\
\text { Study }\end{array}$ & Journal of World Business & $(2018)$ \\
\hline Olivera & $\begin{array}{l}\text { Memory Systems in Organi- } \\
\text { zations: an Empirical } \\
\text { Investigation of Mecha- } \\
\text { nisms for Knowledge } \\
\text { Collection, Storage and } \\
\text { Access }\end{array}$ & $\begin{array}{l}\text { Journal of Management } \\
\text { Studies }\end{array}$ & $(2000)$ \\
\hline $\begin{array}{l}\text { Özcan, Mondragon, Harin- } \\
\text { dranath }\end{array}$ & $\begin{array}{l}\text { Strategic Entry and } \\
\text { Operational Integration of } \\
\text { Emerging Market Firms: } \\
\text { the Case Of Cemex, Beko } \\
\text { And Tata Steel in the UK }\end{array}$ & $\begin{array}{l}\text { Journal of Business } \\
\text { Research }\end{array}$ & (2018) \\
\hline $\begin{array}{l}\text { Paniagua, Korzynski, Mas- } \\
\text { Tur }\end{array}$ & $\begin{array}{l}\text { Crossing Borders with } \\
\text { Social Media: Online } \\
\text { Social Networks and FDI }\end{array}$ & $\begin{array}{l}\text { European Management } \\
\text { Journal }\end{array}$ & (2017) \\
\hline
\end{tabular}




\begin{tabular}{|c|c|c|c|}
\hline Authors & Title & Journal & Pubbl. year \\
\hline Parente, Geleilate, Rong & $\begin{array}{l}\text { The Sharing Economy Glo- } \\
\text { balization Phenomenon: a } \\
\text { Research Agenda }\end{array}$ & $\begin{array}{l}\text { Journal of International } \\
\text { Management }\end{array}$ & (2018) \\
\hline $\begin{array}{l}\text { Peña-Vinces, Cepeda- } \\
\text { Carrion, Chin }\end{array}$ & $\begin{array}{l}\text { Effect of ITC on the Inter- } \\
\text { national Competitiveness } \\
\text { of Firms }\end{array}$ & Management Decision & (2012) \\
\hline Pezderk, Sinkovics & $\begin{array}{l}\text { A Conceptualization of } \\
\text { E-Risk Perceptions and } \\
\text { Implications for Small } \\
\text { Firm Active Online Inter- } \\
\text { nationalization }\end{array}$ & $\begin{array}{l}\text { International Business } \\
\text { Review }\end{array}$ & (2011) \\
\hline Pogrebnyakov & $\begin{array}{l}\text { A Cost-Based Explana- } \\
\text { tion of Gradual, Regional } \\
\text { Internationalization of } \\
\text { Multinationals on Social } \\
\text { Networking Sites }\end{array}$ & $\begin{array}{l}\text { Management International } \\
\text { Review }\end{array}$ & (2017) \\
\hline Prahalad, Ramaswamy & $\begin{array}{l}\text { Co-Opting Customer Com- } \\
\text { petence }\end{array}$ & Harvard Business Review & $(2000)$ \\
\hline Rabbiosi & $\begin{array}{l}\text { Subsidiary Roles and } \\
\text { Reverse Knowledge Trans- } \\
\text { fer: an Investigation of the } \\
\text { Effects of Coordination } \\
\text { Mechanisms }\end{array}$ & $\begin{array}{l}\text { Journal of International } \\
\text { Management }\end{array}$ & $(2011)$ \\
\hline Rangan, Sengul & $\begin{array}{l}\text { Information Technology and } \\
\text { Transnational Integration: } \\
\text { Theory and Evidence } \\
\text { on The Evolution of the } \\
\text { Modern Multinational } \\
\text { Enterprise }\end{array}$ & $\begin{array}{l}\text { Journal of International } \\
\text { Business Studies }\end{array}$ & (2009) \\
\hline Ray, Xue, Barney & $\begin{array}{l}\text { Impact of Information } \\
\text { Technology Capital on } \\
\text { Firm Scope and Perfor- } \\
\text { mance: the Role of Asset } \\
\text { Characteristics }\end{array}$ & $\begin{array}{l}\text { Academy of Management } \\
\text { Journal }\end{array}$ & (2013) \\
\hline $\begin{array}{l}\text { Rothaermel, Kotha, } \\
\text { Steensma }\end{array}$ & $\begin{array}{c}\text { International Market Entry } \\
\text { by US Internet Firms: an } \\
\text { Empirical Analysis of } \\
\text { Country Risk, National } \\
\text { Culture, and Market Size }\end{array}$ & Journal of Management & (2006) \\
\hline Schu, Morschett & $\begin{array}{l}\text { Foreign Market Selection of } \\
\text { Online Retailers-A Path- } \\
\text { Dependent Perspective on } \\
\text { Influence Factors }\end{array}$ & $\begin{array}{l}\text { International Business } \\
\text { Review }\end{array}$ & (2017) \\
\hline Schu, Morschett, Swoboda & $\begin{array}{l}\text { Internationalization Speed } \\
\text { of Online Retailers: a } \\
\text { Resource-Based Perspec- } \\
\text { tive on the Influence } \\
\text { Factors }\end{array}$ & $\begin{array}{l}\text { Management International } \\
\text { Review }\end{array}$ & (2016) \\
\hline Sigfusson, Chetty & $\begin{array}{l}\text { Building International } \\
\text { Entrepreneurial Virtual } \\
\text { Networks in Cyberspace }\end{array}$ & Journal of World Business & (2013) \\
\hline
\end{tabular}




\begin{tabular}{|c|c|c|c|}
\hline Authors & Title & Journal & Pubbl. year \\
\hline Singer & $\begin{array}{l}\text { Systems Marketing for the } \\
\text { Information Age }\end{array}$ & $\begin{array}{l}\text { Mit Sloan Management } \\
\text { Review }\end{array}$ & $(2016)$ \\
\hline Singh, Kundu & $\begin{array}{l}\text { Explaining the Growth of } \\
\text { E-Commerce Corporations } \\
\text { (ECCS): an Extension and } \\
\text { Application of the Eclectic } \\
\text { Paradigm }\end{array}$ & $\begin{array}{l}\text { Journal of International } \\
\text { Business Studies }\end{array}$ & $(2002)$ \\
\hline $\begin{array}{l}\text { Sinkovics, Jean, Roath, } \\
\text { Cavusgil }\end{array}$ & $\begin{array}{l}\text { Does IT Integration Really } \\
\text { Enhance Supplier Respon- } \\
\text { siveness in Global Supply } \\
\text { Chains? }\end{array}$ & $\begin{array}{l}\text { Management International } \\
\text { Review }\end{array}$ & $(2011)$ \\
\hline Strange, Zucchella & $\begin{array}{l}\text { Industry 4.0, Global Value } \\
\text { Chains and International } \\
\text { Business }\end{array}$ & $\begin{array}{l}\text { Multinational Business } \\
\text { Review }\end{array}$ & $(2017)$ \\
\hline $\begin{array}{l}\text { Vendrell-Herrero, Gomes, } \\
\text { Collinson, Parry, Bustinza }\end{array}$ & $\begin{array}{l}\text { Selling Digital Services } \\
\text { Abroad: How Do Extrinsic } \\
\text { Attributes Influence For- } \\
\text { eign Consumers' Purchase } \\
\text { Intentions? }\end{array}$ & $\begin{array}{l}\text { International Business } \\
\text { Review }\end{array}$ & (2018) \\
\hline Wentrup, Nakamura, Ström & $\begin{array}{l}\text { Uberization in Paris-The } \\
\text { Issue of Trust Between } \\
\text { a Digital Platform and } \\
\text { Digital Workers }\end{array}$ & $\begin{array}{l}\text { Critical Perspectives on } \\
\text { International Business }\end{array}$ & (2019) \\
\hline Yamin, Sinkovics & $\begin{array}{l}\text { Online Internationalisation, } \\
\text { Psychic Distance Reduc- } \\
\text { tion and the Virtuality } \\
\text { Trap }\end{array}$ & $\begin{array}{l}\text { International Business } \\
\text { Review }\end{array}$ & $(2006)$ \\
\hline Zaheer, Manrakhan & $\begin{array}{l}\text { Concentration and Disper- } \\
\text { sion in Global Industries: } \\
\text { Remote Electronic Access } \\
\text { and the Location of Eco- } \\
\text { nomic Activities }\end{array}$ & $\begin{array}{l}\text { Journal of International } \\
\text { Business Studies }\end{array}$ & $(2001)$ \\
\hline Zorzini, Stevenson, Hendry & $\begin{array}{l}\text { Customer Enquiry Manage- } \\
\text { ment in Global Supply } \\
\text { Chains: a Comparative } \\
\text { Multi-Case Study Analysis }\end{array}$ & $\begin{array}{l}\text { European Management } \\
\text { Journal }\end{array}$ & $(2012)$ \\
\hline
\end{tabular}

\section{References}

Acker, O. L. A. F., Gröne, F., Schröder, G., \& Geerdes, H. (2012). The global ICT 50: The supply side of digitization. Strategy + Business, 68, 1-9.

Adetayo, J. O., Sanni, S. A., \& Ilori, M. O. (1999). The impact of information technology on product marketing: A case study of a multinational company in Nigeria. Technovation, 19(11), 691-699.

Alarcón-del-Amo, M., Rialp-Criado, A., \& Rialp-Criado, J. (2018). Examining the impact of managerial involvement with social media on exporting firm performance. International Business Review, $27(2), 355-366$.

Alberti-Alhtaybat, L. V., Al-Htaybat, K., \& Hutaibat, K. (2019). A knowledge management and sharing business model for dealing with disruption: The case of Aramex. Journal of Business Research, 94, 400-407. 
Alcácer, J., Cantwell, J., \& Piscitello, L. (2016). Internationalization in the information age: A new era for places, firms, and international business networks? Journal of International Business Studies, 47(5), 499-512.

Ancona, D. G., Okhuysen, G. A., \& Perlow, L. A. (2001). Taking time to integrate temporal research. Academy of Management Review, 26(4), 512-529.

Andersen, P. H. (2006). Regional clusters in a global world: Production relocation, innovation, and industrial decline. California Management Review, 49(1), 101-122.

Andersson, P., \& Mattsson, L. G. (2015). Service innovations enabled by the "internet of things." The IMP Journal, 9(1), 85-106.

Andersson, U., Dasí, Á., Mudambi, R., \& Pedersen, T. (2016). Technology, innovation and knowledge: The importance of ideas and international connectivity. Journal of World Business, 51(1), $153-162$.

Aria, M., \& Cuccurullo, C. (2017). bibliometrix: An R-tool for comprehensive science mapping analysis. Journal of informetrics, 11(4), 959-975.

Asmussen, C. G., \& Goerzen, A. (2013). Unpacking dimensions of foreignness: Firm-specific capabilities and international dispersion in regional, cultural, and institutional space. Global Strategy Journal, $3(2), 127-149$.

Atewologun, D., Kutzer, R., Doldor, E., Anderson, D., \& Sealy, R. (2017). Individual-level foci of identification at work: a systematic review of the literature. International Journal of Management Reviews, 19(3), 273-295.

Autio, E. (2017). Digitalisation, ecosystems, entrepreneurship and policy. Perspectives into topical issues is society and ways to support political decision making. government's analysis, research and assessment activities policy brief (Vol. 20).

Ben-Ner, A., \& Siemsen, E. (2017). Decentralization and localization of production: The organizational and economic consequences of additive manufacturing (3D Printing). California Management Review, 59(2), 5-23.

Bergh, D. D., Perry, J., \& Hanke, R. (2006). Some predictors of SMJ article impact. Strategic Management Journal, 27(1), 81-100.

Berry, L. L., \& Parasuraman, A. B. R. A. H. A. M. (1993). Building a new academic field-the case of services marketing. Journal of retailing, 69(1), 13.

Beugelsdijk, S., Kostova, T., \& Roth, K. (2017). An overview of Hofstede-inspired country-level culture research in international business since 2006. Journal of International Business Studies, 48(1), $30-47$.

Beugelsdijk, S., Kostova, T., Kunst, V. E., Spadafora, E., \& van Essen, M. (2018). Cultural distance and firm internationalization: A meta-analytical review and theoretical implications. Journal of Management, 44(1), 89-130.

Bianchi, C., \& Mathews, S. (2016). Internet marketing and export market growth in Chile. Journal of Business Research, 69(2), 426-434.

Birkinshaw, J., Ambos, T. C., \& Bouquet, C. (2017). Boundary spanning activities of corporate HQ executives insights from a longitudinal study. Journal of Management Studies, 54(4), 422-454.

Biggiero, L. (2006). Industrial and knowledge relocation strategies under the challenges of globalization and digitalization: The move of small and medium enterprises among territorial systems. Entrepreneurship and Regional Development, 18(6), 443-471.

Bloodgood, J. M., Sapienza, H. J., \& Almeida, J. G. (1996). The internationalization of new high-potential US ventures: Antecedents and outcomes. Entrepreneurship Theory and Practice, 20(4), 61-76.

Bos, W., \& Tarnai, C. (1999). Content analysis in empirical social research. International Journal of Educational Research, 31(8), 659-671.

Brouthers, K. D., Geisser, K. D., \& Rothlauf, F. (2016). Explaining the internationalization of ibusiness firms. Journal of International Business Studies, 47(5), 513-534.

Bürgin, R., \& Mayer, H. (2020). Digital periphery? A community case study of digitalization efforts in Swiss Mountain regions. In R. Bürgin \& H. Mayer (Eds.), Smart village technology (pp. 67-98). Cham: Springer.

Cardinal, L. B., Miller, C. C., \& Palich, L. E. (2011). Breaking the cycle of iteration: Forensic failures of international diversification and firm performance research. Global Strategy Journal, 1(1-2), 175-186.

Cano-Kollmann, M., Hannigan, T. J., \& Mudambi, R. (2018). Global innovation networks-organizations and people. Journal of International Management, 24(2), 87-92. 
Casillas, J. C., \& Acedo, F. J. (2013). Speed in the internationalization process of the firm. International Journal of Management Reviews, 15(1), 15-29.

Certo, S. T., Withers, M. C., \& Semadeni, M. (2017). A tale of two effects: Using longitudinal data to compare within-and between-firm effects. Strategic Management Journal, 38(7), 1536-1556.

Chabowski, B. R., \& Mena, J. A. (2017). A review of global competitiveness research: Past advances and future directions. Journal of International Marketing, 25(4), 1-24.

Chabowski, B. R., Hult, G. T. M., \& Mena, J. A. (2011). The retailing literature as a basis for franchising research: Using intellectual structure to advance theory. Journal of Retailing, 87(3), 269-284.

Chang, S. J. (1995). International expansion strategy of Japanese firms: Capability building through sequential entry. Academy of Management Journal, 38(2), 383-407.

Charalabidis, Y., Karyda, M., Kokolakis, S., \& Loukis, E. (2015). Information systems in a changing economy and society in the Mediterranean region. In MCIS 2015 Proceedings (pp 1-6).

Chari, M. D., Devaraj, S., \& David, P. (2007). International diversification and firm performance: Role of information technology investments. Journal of World Business, 42(2), 184-197.

Chen, L., Shaheer, N., Yi, J., \& Li, S. (2019). The international penetration of ibusiness firms: Network effects, liabilities of outsidership and country clout. Journal of International Business Studies, 50(2), 172-192.

Chen, P. T., \& Chen, J. H. (2015). Implementing cloud-based medical systems in hospitals and strategic implications. Technology Analysis \& Strategic Management, 27(2), 198-218.

Chen, W., \& Kamal, F. (2016). The impact of information and communication technology adoption on multinational firm boundary decisions. Journal of International Business Studies, 47(5), 563-576.

Cheng, C., \& Yang, M. (2017). Enhancing performance of cross-border mergers and acquisitions in developed markets: The role of business ties and technological innovation capability. Journal of Business Research, 81, 107-117.

Child, J., Frynas, J. G., \& Rodriques, S. B. (2009). Psychic distance, its impact and coping modes: Interpretations of SME decision makers. Management International Review, 49(2), 199-224.

Cornelius, B., Landström, H., \& Persson, O. (2006). Entrepreneurial studies: The dynamic research front of a developing social science. Entrepreneurship Theory and Practice, 30(3), 375-398.

Cortellazzo, L., Bruni, E., \& Zampieri, R. (2019). The role of leadership in a digitalized world: A review. Frontiers in psychology, 10, 1938.

Coviello, N., Kano, L., \& Liesch, P. W. (2017). Adapting the Uppsala model to a modern world: Macrocontext and microfoundations. Journal of International Business Studies, 48(9), 1151-1164.

Cuccurullo, C., Aria, M., \& Sarto, F. (2016). Foundations and trends in performance management. A twenty-five years bibliometric analysis in business and public administration domains. Scientometrics, 108(2), 595-611.

Cuervo-Cazurra, A., Mudambi, R., \& Pedersen, T. (2018). The boundaries of the firm in global strategy. Global Strategy Journal, 8(2), 211-219.

Cuervo-Cazurra, A., Mudambi, R., \& Pedersen, T. (2019). Clarifying the relationships between institutions and global strategy. Global Strategy Journal, 9(2), 151-175.

D’Angelo, A., Majocchi, A., \& Buck, T. (2016). External managers, family ownership and the scope of SME internationalization. Journal of World Business, 51(4), 534-547.

D'Mello, M., \& Sahay, S. (2007). "I am kind of a nomad where I have to go places and places"... Understanding mobility, place and identity in global software work from India. Information and Organization, 17(3), 162-192.

Dagnino, G. B., Giachetti, C., La Rocca, M., \& Picone, P. M. (2019). Behind the curtain of international diversification: An agency theory perspective. Global Strategy Journal, 9(4), 555-594.

Degryse, C. (2016). Digitalisation of the economy and its impact on labour markets. ETUI research paper-working paper.

Deng, Z., \& Wang, Z. (2016). Early-mover advantages at cross-border business-to-business e-commerce portals. Journal of Business Research, 69(12), 6002-6011.

Dess, G., Lumpkin, G. T., Eisner, A. B., \& McNamara, G. (2014). Strategic management - text and cases - (7th ed.). New York: McGraw-Hill Education.

Eduardsen, J. S., \& Ivang, R. (2016). Internet-enabled internationalisation: A review of the empirical literature and a research agenda. International Journal of Business Environment, 8(2), 152-175.

Edwards, D. J., Pärn, E., Love, P. E., \& El-Gohary, H. (2017). Research note: Machinery, manumission, and economic machinations. Journal of Business Research, 70, 391-394.

Elango, B. (2004). Geographic scope of operations by multinational companies: An exploratory study of regional and global strategies. European Management Journal, 22(4), 431-441. 
Fainshmidt, S., Smith, A., \& Judge, W. Q. (2016). National competitiveness and Porter's diamond model: The role of MNE penetration and governance quality. Global Strategy Journal, 6(2), 81-104.

Foss, N. J., \& Pedersen, T. (2004). Organizing knowledge processes in the multinational corporation: An introduction. Journal of International Business Studies, 35(5), 340-349.

Franco-Santos, M., \& Otley, D. (2018). Reviewing and theorizing the unintended consequences of performance management systems. International Journal of Management Reviews, 20(3), 696-730.

Frank, A. G., Mendes, G. H., Ayala, N. F., \& Ghezzi, A. (2019). Servitization and industry 4.0 convergence in the digital transformation of product firms: A business model innovation perspective. Technological Forecasting and Social Change, 141, 341-351.

Furrer, O., Thomas, H., \& Goussevskaia, A. (2008). The structure and evolution of the strategic management field: A content analysis of 26 years of strategic management research. International Journal of Management Reviews, 10(1), 1-23.

Gabrielsson, M., \& Gabrielsson, P. (2011). Internet-based sales channel strategies of born global firms. International business review, 20(1), 88-99.

Gabrielsson, M., \& Kirpalani, V. M. (2004). Born globals: How to reach new business space rapidly. International Business Review, 13(5), 555-571.

Ghobakhloo, M. (2019). Determinants of information and digital technology implementation for smart manufacturing. International Journal of Production Research, 1-22.

Gilson, L. L., Maynard, M. T., Jones Young, N. C., Vartiainen, M., \& Hakonen, M. (2015). Virtual teams research: 10 years, 10 themes, and 10 opportunities. Journal of Management, 41(5), 1313-1337.

Glavas, C., \& Mathews, S. (2014). How international entrepreneurship characteristics influence Internet capabilities for the international business processes of the firm. International Business Review, 23(1), 228-245.

Globerman, S., Roehl, T. W., \& Standifird, S. (2001). Globalization and electronic commerce: Inferences from retail brokering. Journal of International Business Studies, 32(4), 749-768.

Gloor, P. A., \& Giacomelli, G. (2014). Reading global clients' signals. MIT Sloan Management Review, 55(3), 23-29.

Goerzen, A. (2018). Small firm boundary-spanning via bridging ties: Achieving international connectivity via cross-border inter-cluster alliances. Journal of International Management, 24(2), 153-164.

Gooris, J., \& Peeters, C. (2016). Fragmenting global business processes: A protection for proprietary information. Journal of International Business Studies, 47(5), 535-562.

Grant, R. M. (2016). Contemporary strategy analysis: Text and (cases). New York: Wiley.

Hannibal, M., \& Knight, G. (2018). Additive manufacturing and the global factory: Disruptive technologies and the location of international business. International Business Review, 27(6), 1116-1127.

Hitt, M. A., Tihanyi, L., Miller, T., \& Connelly, B. (2006). International diversification: Antecedents, outcomes, and moderators. Journal of Management, 32(6), 831-867.

Hutzschenreuter, T., Kleindienst, I., \& Lange, S. (2016). The concept of distance in international business research: A review and research agenda. International Journal of Management Reviews, 18(2), $160-179$.

Jacobides, M. G., \& Kudina, A. (2013). How industry architectures shape firm success when expanding in emerging economies. Global Strategy Journal, 3(2), 150-170.

Javalgi, R. R. G., Todd, P. R., Johnston, W. J., \& Granot, E. (2012). Entrepreneurship, muddling through, and Indian Internet-enabled SMEs. Journal of Business Research, 65(6), 740-744.

Jean, R. J. B., Sinkovics, R. R., \& Cavusgil, S. T. (2010). Enhancing international customer-supplier relationships through IT resources: A study of Taiwanese electronics suppliers. Journal of International Business Studies, 41(7), 1218-1239.

Jeong, S. W. (2016). Types of foreign networks and internationalization performance of Korean SMEs. The Multinational Business Review, 24(1), 47-61.

Joensuu-Salo, S., Sorama, K., Viljamaa, A., \& Varamäki, E. (2018). Firm performance among internationalized SMEs: The interplay of market orientation, marketing capability and digitalization. Administrative Sciences, 8(3), 31.

Jurowetzki, R., Lema, R., \& Lundvall, B. Å. (2018). Combining innovation systems and global value chains for development: Towards a research agenda. The European Journal of Development Research, 30(3), 364-388.

Kane, G. C., Palmer, D., Phillips, A. N., \& Kiron, D. (2014). Finding the value in social business. MIT Sloan Management Review, 55(3), 81. 
Khanagha, S., Ramezan Zadeh, M. T., Mihalache, O. R., \& Volberda, H. W. (2018). Embracing bewilderment: Responding to technological disruption in heterogeneous market environments. Journal of Management Studies, 55(7), 1079-1121.

Kim, D., Jean, R. J. B., \& Sinkovics, R. R. (2018). Drivers of virtual interfirm integration and its impact on performance in international customer-supplier relationships. Management international review, 58(3), 495-522.

Kirca, A. H., Roth, K., Hult, G. T. M., \& Cavusgil, S. T. (2012). The role of context in the multinationality-performance relationship: A meta-analytic review. Global Strategy Journal, 2(2), 108-121.

Kotha, S., Rindova, V. P., \& Rothaermel, F. T. (2001). Assets and actions: Firm-specific factors in the internationalization of US Internet firms. Journal of International Business Studies, 32(4), 769-791.

Kraus, S., Palmer, C., Kailer, N., Kallinger, F. L., \& Spitzer, J. (2018). Digital entrepreneurship: a research agenda on new business models for the twenty-first century. International Journal of Entrepreneurial Behavior \& Research, 25, 353-375.

Kutnjak, A., Pihiri, I., \& Furjan, M. T. (2019, May). Digital transformation case studies across industries-literature review. In 2019 42nd international convention on information and communication technology, electronics and microelectronics (MIPRO) (pp. 1293-1298). IEEE.

Lagerström, K., \& Andersson, M. (2003). Creating and sharing knowledge within a transnational teamThe development of a global business system. Journal of World Business, 38(2), 84-95.

Lampel, J., \& Giachetti, C. (2013). International diversification of manufacturing operations: Performance implications and moderating forces. Journal of Operations Management, 31(4), 213-227.

Langley, A., \& Truax, J. (1994). A process study of new technology adoption in smaller manufacturing firms. Journal of Management Studies, 31(5), 619-652.

Langlois, R. N. (2002). Modularity in technology and organization. Journal of Economic Behavior \& Organization, 49(1), 19-37.

Leamer, E. E., \& Storper, M. (2001). The economic geography of the internet age. Journal of International Business Studies, 32(4), 641.

Lee, Y. Y., \& Falahat, M. (2019). The impact of digitalization and resources on gaining competitive advantage in international markets: Mediating role of marketing, innovation and learning capabilities. Technology Innovation Management Review, 9(11), 26-39.

Lee, S. H., Oh, C. H., \& Lee, J. Y. (2017). The effect of host country Internet infrastructure on foreign expansion of Korean MNCs. Asia Pacific Business Review, 23(3), 396-419.

Legner, C., Eymann, T., Hess, T., Matt, C., Böhmann, T., Drews, P., et al. (2017). Digitalization: Opportunity and challenge for the business and information systems engineering community. Business \& information systems engineering, 59(4), 301-308.

Liesch, P. W., Håkanson, L., McGaughey, S. L., Middleton, S., \& Cretchley, J. (2011). The evolution of the international business field: A scientometric investigation of articles published in its premier journal. Scientometrics, 88(1), 17-42.

Lin, H. C., Swarna, H., \& Bruning, P. F. (2017). Taking a global view on brand post popularity: Six social media brand post practices for global markets. Business Horizons, 60(5), 621-633.

Liu, X., Gao, L., Lu, J., \& Lioliou, E. (2016). Environmental risks, localization and the overseas subsidiary performance of MNEs from an emerging economy. Journal of World Business, 51(3), 356-368.

Lovelock, C. H., \& Yip, G. S. (1996). Developing global strategies for service businesses. California Management Review, 38(2), 64-86.

Lu, J. W., \& Beamish, P. W. (2004). International diversification and firm performance: The S-curve hypothesis. Academy of Management Journal, 47(4), 598-609.

Luo, Y., \& Bu, J. (2016). How valuable is information and communication technology? A study of emerging economy enterprises. Journal of World Business, 51(2), 200-211.

Luz Martín-Peña, M., Díaz-Garrido, E., \& Sánchez-López, J. M. (2018). The digitalization and servitization of manufacturing: A review on digital business models. Strategic Change, 27(2), 91-99.

Majocchi, A., \& Strange, R. (2012). International diversification. Management International Review, 52(6), 879-900.

Marano, V., Arregle, J. L., Hitt, M. A., Spadafora, E., \& van Essen, M. (2016). Home country institutions and the internationalization-performance relationship: A meta-analytic review. Journal of Management, 42(5), 1075-1110.

Martin, B. R. (2012). The evolution of science policy and innovation studies. Research Policy, 41(7), 1219-1239. 
Mathews, S., Bianchi, C., Perks, K. J., Healy, M., \& Wickramasekera, R. (2016). Internet marketing capabilities and international market growth. International Business Review, 25(4), 820-830.

Matysiak, L., \& Bausch, A. (2012). Antecedents of MNE performance: Blinded by the obvious in 35 years of literature. Multinational Business Review, 20, 178-211.

Mendes, M. V. I. (2020). The limitations of international relations regarding MNCs and the digital economy: Evidence from Brazil. Review of Political Economy. https://doi.org/10.1080/09538259.2020. 1730609

Meyer, A. D., Tsui, A. S., \& Hinnings, C. R. (1993). Configurational approaches to organizational analysis. Academy of Management Journal, 35(6), 1175-1195.

Mikalef, P., \& Pateli, A. (2017). Information technology-enabled dynamic capabilities and their indirect effect on competitive performance: Findings from PLS-SEM and fsQCA. Journal of Business Research, 70, 1-16.

Molodchik, M., \& Jardon, C. M. (2017). Intellectual capital as enhancer of product novelty: An empirical study of Russian manufacturing SMEs. Journal of Intellectual Capital, 18(2), 419-436.

Montoro-Sanchez, A., Diez-Vial, I., \& Belso-Martinez, J. A. (2018). The evolution of the domestic network configuration as a driver of international relationships in SMEs. International Business Review, 27(4), 727-736.

Moral-Pajares, E., Mozas-Moral, A., Bernal-Jurado, E., \& Medina-Viruel, M. J. (2015). Efficiency and exports: Evidence from Southern European companies. Journal of Business Research, 68(7), 1506-1511.

Mozas-Moral, A., Moral-Pajares, E., Medina-Viruel, M. J., \& Bernal-Jurado, E. (2016). Manager's educational background and ICT use as antecedents of export decisions: A crisp set QCA analysis. Journal of Business Research, 69(4), 1333-1335.

Nerur, S. P., Rasheed, A. A., \& Natarajan, V. (2008). The intellectual structure of the strategic management field: An author co-citation analysis. Strategic Management Journal, 29(3), 319-336.

Ojala, A., Evers, N., \& Rialp, A. (2018). Extending the international new venture phenomenon to digital platform providers: A longitudinal case study. Journal of World Business, 53(5), 725-739.

Olivera, F. (2000). Memory systems in organizations: An empirical investigation of mechanisms for knowledge collection, storage and access. Journal of management studies, 37(6), 811-832.

Özcan, G. B., Mondragon, A. E. C., \& Harindranath, G. (2018). Strategic entry and operational integration of emerging market firms: The case of Cemex, Beko and Tata Steel in the UK. Journal of Business Research, 93, 242-254.

Paniagua, J., Korzynski, P., \& Mas-Tur, A. (2017). Crossing borders with social media: Online social networks and FDI. European Management Journal, 35(3), 314-326.

Parente, R. C., Geleilate, J. M. G., \& Rong, K. (2018). The sharing economy globalization phenomenon: A research agenda. Journal of International Management, 24(1), 52-64.

Parida, V., Sjödin, D., \& Reim, W. (2019). Reviewing literature on digitalization, business model innovation, and sustainable industry: Past achievements and future promises. Sustainability, 11, 391.

Parviainen, P., Tihinen, M., Kääriäinen, J., \& Teppola, S. (2017). Tackling the digitalization challenge: How to benefit from digitalization in practice. International Journal of Information Systems and Project Management, 5(1), 63-77.

Peña-Vinces, J. C., Cepeda-Carrión, G., \& Chin, W. W. (2012). Effect of ITC on the international competitiveness of firms. Management Decision, 50, 1045.

Pezderka, N., \& Sinkovics, R. R. (2011). A conceptualization of e-risk perceptions and implications for small firm active online internationalization. International Business Review, 20(4), 409-422.

Pihir, I., Tomičić-Pupek, K., \& Tomičić Furjan, M. (2019). Digital transformation playground-literature review and framework of concepts. Journal of Information and Organizational Sciences, 43(1), 33-48.

Pogrebnyakov, N. (2017). A cost-based explanation of gradual, regional internationalization of multinationals on social networking sites. Management International Review, 57(1), 37-64.

Prahalad, C. K., \& Ramaswamy, V. (2000). Co-opting customer competence. Harvard business review, 78(1), 79-90.

Rabbiosi, L. (2011). Subsidiary roles and reverse knowledge transfer: An investigation of the effects of coordination mechanisms. Journal of International Management, 17(2), 97-113.

Rakas, M., \& Hain, D. S. (2019). The state of innovation system research: What happens beneath the surface? Research Policy, 48(9), 103787. 
Ramos-Rodríguez, A. R., \& Ruíz-Navarro, J. (2004). Changes in the intellectual structure of strategic management research: A bibliometric study of the Strategic Management Journal, 1980-2000. Strategic management journal, 25(10), 981-1004.

Rangan, S., \& Sengul, M. (2009). Information technology and transnational integration: Theory and evidence on the evolution of the modern multinational enterprise. Journal of International Business Studies, 40(9), 1496-1514.

Rask, M. (2014). Internationalization through business model innovation: In search of relevant design dimensions and elements. Journal of International Entrepreneurship, 12(2), 146-161.

Ray, G., Xue, L., \& Barney, J. B. (2013). Impact of information technology capital on firm scope and performance: The role of asset characteristics. Academy of Management Journal, 56(4), 1125-1147.

Reis, J., Amorim, M., Melão, N., \& Matos, P. (2018, March). Digital transformation: A literature review and guidelines for future research. In World conference on information systems and technologies (pp. 411-421). Cham: Springer.

Reuber, A. R., \& Fischer, E. (2011). International entrepreneurship in internet-enabled markets. Journal of Business Venturing, 26(6), 660-679.

Rothaermel, F. T., Kotha, S., \& Steensma, H. K. (2006). International market entry by US internet firms: An empirical analysis of country risk, national culture, and market size. Journal of Management, 32(1), 56-82.

Rugg, G., \& McGeorge, P. (1997). The sorting techniques: A tutorial paper on card sorts, picture sorts and item sorts. Expert Systems, 14(2), 80-93.

Saggese, S., Sarto, F., \& Cuccurullo, C. (2016). Evolution of the debate on control enhancing mechanisms: A systematic review and bibliometric analysis. International Journal of Management Reviews, 18(4), 417-439.

Sarto, F., Cuccurullo, C., \& Aria, M. (2014). Exploring healthcare governance literature: Systematic review and paths for future research. Mecosan, 23, 61-80.

Schildt, H. A., Zahra, S. A., \& Sillanpää, A. (2006). Scholarly communities in entrepreneurship research: A co-citation analysis. Entrepreneurship Theory and Practice, 30(3), 399-415.

Schmidt, E., \& Cohen, J. (2013). The new digital age: Reshaping the future of people, nations and business. London: Hachette.

Schu, M., \& Morschett, D. (2017). Foreign market selection of online retailers-A path-dependent perspective on influence factors. International Business Review, 26(4), 710-723.

Schu, M., Morschett, D., \& Swoboda, B. (2016). Internationalization speed of online retailers: A resource-based perspective on the influence factors. Management International Review, 56(5), $733-757$.

Schwab, K. (2016). The fourth industrial revolution. Switzerland: World Economic Forum.

Seyedghorban, Z., Tahernejad, H., Meriton, R., \& Graham, G. (2020). Supply chain digitalization: Past, present and future. Production Planning \& Control, 31(2-3), 96-114.

Sigfusson, T., \& Chetty, S. (2013). Building international entrepreneurial virtual networks in cyberspace. Journal of World Business, 48(2), 260-270.

Singer, J. G. (2006). Systems marketing for the information age. MIT Sloan Management Review, 48(1), 95.

Singh, N., \& Kundu, S. (2002). Explaining the growth of e-commerce corporations (ECCs): An extension and application of the eclectic paradigm. Journal of International Business Studies, 33(4), 679-697.

Sinkovics, N., Sinkovics, R. R., \& "Bryan” Jean, R. J. (2013). The internet as an alternative path to internationalization? International Marketing Review, 30(2), 130-155.

Sinkovics, R. R., Jean, R. J. B., Roath, A. S., \& Cavusgil, S. T. (2011). Does IT integration really enhance supplier responsiveness in global supply chains? Management International Review, 51(2), 193.

Stolterman, E., \& Fors, A. C. (2004). Information technology and the good life. In Information systems research (pp. 687-692). Boston, MA: Springer.

Strange, R., \& Zucchella, A. (2017). Industry 4.0, global value chains and international business. Multinational Business Review, 25(3), 174-184.

Tan, B. R., \& Chintakananda, A. (2016). The effects of home country political and legal institutions on firms' geographic diversification performance. Global Strategy Journal, 6(2), 105-123.

Tihinen, M., Iivari, M., Ailisto, H., Komi, M., Kääriäinen, J., \& Peltomaa, I. (2016, October). An exploratory method to clarify business potential in the context of industrial internet-A case study. In Working conference on virtual enterprises (pp. 469-478). Cham: Springer. 
Torchia, M., Calabrò, A., \& Morner, M. (2015). Public-private partnerships in the health care sector: A systematic review of the literature. Public Management Review, 17(2), 236-261.

Vadana, I. I., Torkkeli, L., Kuivalainen, O., \& Saarenketo, S. (2019). Digitalization of companies in international entrepreneurship and marketing. International Marketing Review. https://doi.org/10.1108/ IMR-04-2018-0129

Vasilchenko, E., \& Morrish, S. (2011). The role of entrepreneurial networks in the exploration and exploitation of internationalization opportunities by information and communication technology firms. Journal of International Marketing, 19(4), 88-105.

Vendrell-Herrero, F., Gomes, E., Collinson, S., Parry, G., \& Bustinza, O. F. (2018). Selling digital services abroad: How do extrinsic attributes influence foreign consumers' purchase intentions? International Business Review, 27(1), 173-185.

Watson, G. F., IV., Weaven, S., Perkins, H., Sardana, D., \& Palmatier, R. W. (2018). International market entry strategies: Relational, digital, and hybrid approaches. Journal of International Marketing, 26(1), 30-60.

Wentrup, R., Nakamura, H. R., \& Ström, P. (2019). Uberization in Paris-the issue of trust between a digital platform and digital workers. Critical Perspectives on International Business, 15(1), $20-41$.

Werner, S. (2002). Recent developments in international management research: A review of 20 top management journals. Journal of Management, 28(3), 277-305.

Wheelen, T. L., \& Hunger, J. D. (2012). Strategic management and business policy-Toward global sustainability (13th ed.). USA: Pearson Education.

Wittkop, A., Zulauf, K., \& Wagner, R. (2018). How digitalization changes the internationalization of entrepreneurial firms: Theoretical considerations and empirical evidence. Management Dynamics in the Knowledge Economy, 6(2), 193-207.

Wright, R. W., \& Ricks, D. A. (1994). Trends in international business research: Twenty-five years later. Journal of international business studies, 25(4), 687-701.

Yamin, M., \& Sinkovics, R. R. (2006). Online internationalisation, psychic distance reduction and the virtuality trap. International Business Review, 15(4), 339-360.

Zaheer, S., \& Manrakhan, S. (2001). Concentration and dispersion in global industries: Remote electronic access and the location of economic activities. Journal of International Business Studies, 32(4), 667-686.

Zahra, S. A., \& George, G. (2002). International entrepreneurship: The current status of the field and future research agenda. In M. A. Hitt, R. D. Ireland, S. M. Sexton, \& D. L. Camp (Eds.), Strategic entrepreneurship: Creating an integrated mindset (pp. 255-288). Strategic Management Series. Oxford: Blackwell.

Zhou, N., \& Guillen, M. F. (2016). Categorizing the liability of foreignness: Ownership, location, and internalization-specific dimensions. Global Strategy Journal, 6(4), 309-329.

Zolfagharian, M., Romme, A. G. L., \& Walrave, B. (2018). Why, when, and how to combine system dynamics with other methods: Towards an evidence-based framework. Journal of Simulation, 12(2), 98-114.

Zorzini, M., Stevenson, M., \& Hendry, L. C. (2012). Customer enquiry management in global supply chains: A comparative multi-case study analysis. European Management Journal, 30(2), 121-140.

Zucchella, A., Palamara, G., \& Denicolai, S. (2007). The drivers of the early internationalization of the firm. Journal of World Business, 42(3), 268-280.

Zupic, I., \& Čater, T. (2015). Bibliometric methods in management and organization. Organizational Research Methods, 18(3), 429-472.

Publisher's Note Springer Nature remains neutral with regard to jurisdictional claims in published maps and institutional affiliations.

Mara Bergamaschi is Full Professor of Management at the University of Bergamo, Italy. She previously worked at the Bocconi University, Milano. Her research interests include behavioral and strategic aspects in professional service firms and family businesses as well as marketing and branding in business and consumer markets. Her research work has been published in various outlets, including Journal of Business Research, Journal of Service Theory and Practice, International Journal of Business and Management, Industrial Marketing Management and Journal of Business Ethics. 
Cristina Bettinelli is Associate Professor of Management at the University of Bergamo, Italy. She received her Ph.D. in Marketing and Strategy from the University of Bergamo. She has held visiting positions at Harvard University and Linz University among the others. Her research interests rotate around the family nature of firms' manifestation in behavioral and strategic aspects. Her research work has been published in various outlets, including Family Business Review, Journal of Business Research, Management International Review, International Business Review, Journal of Small Business Economics and Small Business Economics among the others.

Elena Lissana is a Ph.D. Candidate in Business and Law at the University of Bergamo, Italy. Her main research interests include the management of family businesses, organizational identities, and growth strategies. She got a master's degree in International Management, Entrepreneurship and Finance from University of Bergamo with distinction.

Pasquale Massimo Picone is Associate Professor of Management at the University of Palermo, Italy. He previously worked at the University of Bergamo and at the University of Catania, where he received his Ph.D. in Business Economics \& Management. He has held visiting positions at Texas A\&M University and IE Business School in Madrid. His research interests include the management of diversified corporate portfolios; the sources, symptoms, and consequences of managerial hubris; and the temporary competitive advantage. His research work has been published in various outlets, including Academy of Management Perspectives, Global Strategy Journal, Corporate Governance: An International Review, Journal of Business and Industrial Marketing, Journal of Management and Governance, and Business Horizons.

\section{Affiliations}

\section{Mara Bergamaschi ${ }^{1}$. Cristina Bettinelli ${ }^{1}$ Elena Lissana ${ }^{1}$. Pasquale Massimo Picone ${ }^{2}$}

Cristina Bettinelli

cristina.bettinelli@unibg.it

Elena Lissana

elena.lissana@unibg.it

Pasquale Massimo Picone

pasqualemassimo.picone@unipa.it

1 Department of Management, University of Bergamo, Via dei Caniana, 2, 24127 Bergamo, BG, Italy

2 Department of Economics, Business, and Statistics, University of Palermo, Viale delle Scienze - Building n.13, 90128 Palermo, Italy 